\title{
Agrarian and Mercantile Ideologies in Western Han
}

\author{
Roel Sterckx \\ University of Cambridge, Cambridge, UK \\ rsiooog@cam.ac.uk
}

\begin{abstract}
This paper questions the conventional scholarly view that early Chinese economic thought simply conceived of farming and commerce as mutually opposing forces. It argues that during Western Han times there existed a significant distance between court rhetoric and economic reality and suggests that, in reading official discourse, one should be cautious not to emphasize the economic over the political. The paper re-examines a series of well-known court memorials and concludes that few questioned the ethics of how wealth should be generated as long as political control could be maintained and the Han court was on the receiving end of it.
\end{abstract}

\section{Keywords}

early China - professions - economics - Han dynasty

\section{Introduction}

In 181 C.E., Emperor Ling 漢靈帝 (Han Lingdi, r. 168-189) thought up an activity to amuse himself and his courtiers. According to the Hou Hanshu 後漢書 [Book of the Later Han] he "set up market stands in the rear palace and ordered all his chosen ladies to deal and sell goods and, furthermore, to steal from and struggle against each other." The emperor, we are told, dressed himself in merchant's garments (shang gu fu 商估服), and drank, feasted and made

1 Hou Hanshu 後漢書, compiled by Fan Ye 范瞱 (398-445 CE) et al. (Beijing: Zhonghua Shuju, 1965): 8.346; cf. Ch'ü T'ung-tsu 矍同祖, Han Social Structure (Seattle and London: University of Washington Press, 1972): 391, no. 86. 
merry. ${ }^{2}$ Light-hearted pretend play to break the monotony of palace life was hardly out of the ordinary (much of Lingdi's reign saw a court dominated by eunuchs). Yet the anecdote is noteworthy because of the theme that makes up this mocking scene of ordinary life. Playing market and merchant, enjoying the sight of concubines haggling and squabbling over the price of goods, and dressing up like a hawker are the chosen distraction from the ritualised order that dominates court life.

When the Han house was established nearly four centuries earlier, the thought that a Son of Heaven would dally with the world of merchants and tradesmen would have been anathema. At court nearly every emperor during Western Han was urged to promote agriculture over mercantile activity, and anti-mercantile rhetoric was rife. ${ }^{3}$ At no point in the public calendar would an emperor be seen to patronize the markets or support merchants. The Eastern and Western Market in the capital Chang'an 長安 were located in the northwestern part of the city, and public access to the markets was restricted to three out of nine city gates to ensure that merchants and their entourage were kept well away from the imperial palaces. ${ }^{4}$ By contrast, state ritual required that the emperor put his hands to the plough during an annual ploughing ceremony on designated sacred fields. ${ }^{5}$

Numerous Han voices rehearsed the age old adagio that sage rulers must place virtue over material concerns, and put righteousness over profit. In

2 A passage in Sanguo zhi 三國志 [Records of the Three Kingdoms], compiled by Chen Shou 陳壽 (233-297 CE) (Beijing: Zhonghua Shuju, 1959): 54.1278, suggests that merchants may have worn white garments, but we have no detail about style.

3 Hanshu 漢書 [Book of Han], compiled by Ban Gu 班固 (32-92 CE) (Beijing: Zhonghua Shuju, 1962): 4.117, 4.125 (Emperor Wen 文帝, 167 BCE); 5.152 (Emperor Jing 景帝, 141 BCE); 29.1685 (Emperor Wudi 武帝, 111 BCE); 7.232 (Emperor Zhao 昭帝, r. 87-74 BCE); 8.245 (Emperor Xuan 宣帝, r. 74-49 BCE). Shao Yiping 邵毅平 notes that merchants only rarely appear in Han poetry, ballads, or other literary texts. See Shao Yiping, Zhongguo wenxue zhong de shangren shijie 中国文学中的商人世界 [The World of Merchants in Chinese Literature] (Shanghai: Fudan Daxue Chubanshe, 2005): 32-49.

4 Anthony Barbieri-Low, Artisans in Early Imperial China (Seattle \& London: University of Washington Press, 2007): 118-31. On regional markets beyond the capital see Gao Weigang 高维刚, Qin Han shichang yanjiu 秦汉市场研究 [A Study of Markets during Qin and Han] (Chengdu: Sichuan Daxue Chubanshe, 2008): 108-36. The Zhangjiashan 張家山 legal documents (186 вСE, Jiangling, Hubei) prescribe punishment by tattooing for scaling a market wall. See Zhangjiashan ershiqi hao Han mu zhujian zhengli xiaozu, Zhangjiashan Han mu zhujian [ershiqi hao mu] 張家山漢墓竹簡 [二十七號墓], revised. ed. (Beijing: Wenwu Chubanshe, 2006): 33 (slip 182).

5 The annual ploughing ceremony is well studied in Derk Bodde, Festivals in Classical China: New Year and other annual observances during the Han dynasty, 206 B.C.-A.D. 220 (Princeton: Princeton University Press, 1975): 223-41. 
moralist rhetoric, the merchant represented greed, moral decay, excess, and the weakening of central power and the public good. By contrast, farming connoted moral integrity, productivity, economic stimulus, communal labour, the sharing of wealth, and being tied to land and locality. Nobody questioned that it was the task of those in power to secure basic welfare for the people, yet it was acknowledged that controlling the circulation of goods and people was a difficult charge. As the Daxue 大學 once put it: "When goods are concentrated, people will be scattered. When goods are scattered, people will be concentrated" (是故財聚則民散, 財散則民聚). ${ }^{6}$ A perceived tension between farming and commerce also left traces in the historiography of the period. Whereas Sima Qian 司馬遷 (ca. 145-ca. 87 BCE) undertook to write about the diverse components of economic life without insisting on a radical hierarchy among the professions, Ban Gu's 班固 (32-92 CE) treatise on economic history (Hanshu [The Book of Han], chapter 24), reflecting back less than two centuries later, separates the discussion of agriculture from mercantile activity. ${ }^{7}$ Its title puts shi 食, "food," before huo 貨, "goods," and the treatise starts off with a history of agricultural policies from antiquity up to the end of the Wang Mang 王莽 interregnum (9-23 C.E.). The second part then deals with monetary, fiscal, and commercial policy. ${ }^{8}$

Both historians note an anti-mercantile turn in the form of a series of welldocumented measures. As early as the reign of Gaozu 高祖 (Han Gaodi 漢高帝,

6 Liji zhushu 禮記注疏 [The Record of Rites with commentaries and subcommentaries], annotated by Kong Yingda 孔穎達 (574-648 CE), Shisanjing zhushu edition (collated by Ruan Yuan 阮元 [1764-1849]; rpt. Taizhong: Landeng, n.d.), vol. 5: 6o.10a.

7 For an excellent analysis of the different positions taken by Sima Qian and Ban Gu, see Hans van Ess, Politik und Geschichtsschreibung im alten China (Wiesbaden: Harrassowitz Verlag, 2014), vol. 2: 567-618.

8 Shi 食 and huo 貨 first occur as generic terms for economic welfare in the "Warring States" strata of the Shangshu 尚書. See Shangshu zhengyi 尚書正義 [The Correct Meanings of the Book of Documents], annotated by Kong Yingda 孔穎達 et al. (Shisanjing zhushu edition): 12.9 (“Hong fan” 洪範). See further Zhu Jiazhen 朱家禎, “Shangshu' ji buci jinwen zhong de jingji sixiang” 尚書及卜辭金文中的經濟思想 [“Economic Thought in the Book of Documents, Oracle Bone and Bronze Inscriptions"], in Xian Qin jingji sixiang shi 先秦经 济思想史 [A History of Economic Thought in the Pre-Qin Period], ed. Wu Baosan 巫宝 三 (Beijing: Zhongguo Shehui Kexue Chubanshe, 1996): 6o-79. The terms form the title of the treatise on economics ("Shi huo zhi" 食貨志) in successive dynastic histories. The Shiji treatise (Shiji 30) is entitled “Ping zhun shu” 平隼書 [Treatise on Price Standardization] and mostly deals with the early Western Han and the reigns of Han Wudi. Shiji 史記 [Records of the Grand Historian], by Sima Qian (Beijing: Zhonghua Shuju, 1959): ch. 129, "Huo zhi liezhuan" 貨殖列傳 ["Exemplary Traditions on the Proliferation of Goods]," including biographies of merchants, derives its title from a statement by Confucius on Zi Gong's 子貢 ambition to pursue wealth (cf. Lunyu [Analects], 11.19). 
206-195 BCE), merchants were forbidden to display their wealth by wearing silk or travelling on horseback. Merchants and their descendants were not permitted to become officials, and they were subject to heavier taxes. ${ }^{9}$ Under Huidi 惠帝 (195-188 BCE) there was a temporary relaxation, although the ban that prevented descendants of merchants from becoming officials stayed in place. Han Wudi 漢武帝 (141-87 BCE) raised the severity of these anti-mercantile measures, extended the power of taxation over the so-called travelling merchants, and prohibited registered merchants and their families from owning land. ${ }^{10}$ Poll tax rates on merchants and slaves were double those for ordinary people." Tax on property, first imposed in $203 \mathrm{BCE}$, was raised in $119 \mathrm{BCE}$ for merchants and manufacturers. Vehicles belonging to merchants were taxed double. In

Shiji, 30.1418; Hanshu, 24B.1153. Huan Tan 桓譚 (ca. 43 BCE-28 CE), in Hou Hanshu, 28A.958, reflects back on these measures: "The way to regulate a state is to promote the basic occupation and to suppress extraneous profits. Therefore, the emperors of earlier times prohibited one person from practicing two professions (ren erye 人二業) and forbade travelling traders and resident merchants from serving as officials. By these methods, they prevented the accumulation and acquisition of the fields of the poor by the rich and powerful and promoted a sense of modesty and shame." Cf. Timoteus Pokora, Hsin-lun (New Treatises) and Other Writings by Huan T'an (43 BC-28 AD) (Ann Arbor: Center for Chinese Studies, University of Michigan, 1975): 237.

10 While the use of the terms fluctuates, generally shang 商 refers to itinerant merchants who traded between cities and markets, whereas $g u$ 賈 were merchants trading in shops or stalls of urban marketplaces where they were registered. For Ban Gu's definition of the terms see Bohutong shu zheng 白虎通疏證 [The Comprehensive Discussions in the White Tiger Hall with commentaries], compiled by Ban Gu et al., annotated by Wu Zeyu 吳則虞 (Beijing: Zhonghua Shuju, 1994):7·346-47. Gu is the earlier term for merchants or mercantile activity and is used as such in oracle bones and Western Zhou bronze inscriptions. See Zhu Honglin 朱红林, Zhouli zhong shangye guanli zhidu yanjiu 周礼中商业管 理制度研究 [A Study of the System of Commerce Management in the Rites of Zhou] (Changchun: Jilin Wenshi Chubanshe, 2003): 31-41. Han merchants were issued with passports and transit documents that mentioned the destination markets where they intended to trade. See Daniel Sungbin Sou, "Crossing Borders: Control of Geographical Mobility in Early China." T'oung Pao 104 (2018): 243-47.

11 Han taxation was levied in cash, kind, or statutory labour. Taxation per head of population $(f u$ 賦) was the main principle, supplemented by taxation on produce and earnings from land ( $z u$ 租). Most taxes were paid in money, as opposed to kind. The merchant tax was known as shi zu市租, the tax on produce from the seas as hai $z u$ 海租. In principle land-tax (tian $z u$ 田租) was to be paid in kind (grain, textiles) but peasants were involved significantly in the monetary economy either directly, or, more likely, through the agency of middlemen or merchants who traded their produce for cash (and took a cut!). For recent studies see Zang Zhifei 臓知非, Qin Han tudi fuyi zhidu yanjiu 秦汉土地賦役制度 研究 [A Study of the Land Tax and Corvée System in Qin and Han] (Beijing: Zhongyang Bianyi Chubanshe, 2017): 112-306; Wang Yanhui 王彦辉, Qin Han huji guanliyu fuyi zhidu yanjiu 秦汉户籍管理与赋役制度研究 [A Study of the Management of Household Registers and the Tax System in Qin and Han] (Beijing: Zhonghua Shuju, 2016): 121-29o. 
addition to tax rises, there were monopolies on salt and iron (119 BCE), a less successfully implemented monopoly on alcohol (98 вСE, withdrawn in $81 \mathrm{BCE}$ ), and the introduction of the "equal supply/transportation" (jun shu 均輸, 110 BCE), ${ }^{12}$ and "price standardization" (ping zhun 平准, 115 BCE) schemes. ${ }^{13}$ Official prohibitions on access to officialdom and land ownership remained on the books throughout Western Han. ${ }^{14}$

There is little evidence suggesting that a peasant-merchant dichotomy was articulated with force before the Han, the Shangjun shu 商君書 [Book of Lord Shang] being the notable exception. ${ }^{15}$ Our reading of Zhanguo and Qin sources may have been influenced by over-idealized Han views of farming and anti-mercantile sentiments that were projected back in time. ${ }^{16}$ In the 195os, Yang Lien-sheng hinted that the farmer versus merchant model was "overdrawn." ${ }^{17}$ Likewise, the Western Han itself was not an unequivocal hotbed

12 Hanshu, 24B.1174; Yantie lun jiaozhu 鹽鐵論校注 [The Debates on Salt and Iron with annotations and commentary], compiled by Huan Kuan 桓寬 (1st century BCE), annotated by Wang Liqi 王利器 (Beijing: Zhonghua Shuju, 1996): 1.4 (“Ben yi”). Although the details are not entirely clear, the basic idea was that the government would purchase goods with tax proceeds and organize their transport, thereby cutting out merchants as middlemen and channeling profits to the central coffers.

13 Government would buy and store local products and sell them when prices rose, thereby lowering prices to the detriment of merchants but to the advantage of the common population. Note that allthese measures are the subject of severe criticism by the literati party in the Yantie lun discussed later (especially in its opening chapter). The establishment of "ever level granaries" (changping cang 常平倉) (54-44 BCE) was another attempt at stabilizing grain prices. See Hanshu, 24A.1141; and Liu Jiapeng 刘甲朋, Zhongguo gudai liangshi chubei tiaojie zhidu sixiang yanjin 中国古代粮食储备调节制度思想演 进 [Evolving Ideologies of the System of Regulation for the Storage of Grain Reserves in Ancient China] (Beijing: Zhongguo Jingji Chubanshe, 2010): 87-94.

14 There is mention of it in an edict of 7 BCE during Aidi's 哀帝 reign (7-1 BCE). See Hanshu, 11.336. As Hans Bielenstein notes, the fact that the edict excluding merchants from officialdom was restated suggests that it was broken at times. See Bielenstein, The Bureaucracy of Han Times (Cambridge: Cambridge University Press, 1980): 132.

15 See Roel Sterckx, "Ideologies of the peasant and merchant in Warring States China," in Ideology of Power and Power of Ideology in Early China, ed. Yuri Pines, Paul Rakita Goldin, and Martin Kern (Leiden: Brill, 2015): 217-23; and Romain Graziani, "What's in a Slogan. The Political Rationale behind 'Enrich the State, Strengthen the Army' (富國強兵) and its economic quandary." In Keywords in Chinese Culture, ed. Li Wai-yee and Yuri Pines (Hong Kong: The Chinese University Press, 2019): 123-68 (sub section 4).

16 Cf. Sterckx, "Ideologies of the peasant and merchant in Warring States China."

17 Yang Lien-sheng 楊聯陸, “Economic Justification for Spending一An Uncommon Idea in Traditional China." Harvard Journal of Asiatic Studies 20/1-2 (1957): 36-52 (esp. p. 40). For variations of the argument that merchants in Warring States times did not suffer low esteem to the degree that would emerge in Western Han, see Luo Genze 羅根澤, “Gudai jingjixue zhong zhi ben nong mo shang xue shuo”古代經濟學中之本農末商學説 
of agriculturalist or anti-mercantile sentiment. Were Han governments simply set on discouraging commerce as much as has been suggested? ${ }^{18}$ And, more importantly, to what extent were the arguments based on economics? Michael Loewe's characterization of Western Han opinion as "modernist-realist" versus "reformist-idealist", an analysis he applied to ideas and political positions beyond economic thought, provides a good starting point:

Two distinct views of the merchant and his occupation stand revealed in the official writings of Han times. Some took the view that, classed with the artisans, traders were to be seen as engaging in work that was of secondary importance to the empire, and such an attitude may have gained general acceptance in official corners. By contrast those men who were of a practical frame of mind, such as Sang Hongyang [...] recognized that farmer, artisan and merchant all had their part to play in utilizing or exploiting the resources of the empire and distributing them for general benefit. [...] As against the call heard sometimes for a life of thrift, and a reduction of extravagance, there may have been some attempt to promote trade by the consumption of luxurious products and articles of manufacture. ${ }^{19}$

["The Theory of The Primacy of Agriculture and Subsidiarity of Commerce in the Study of Ancient Economics"], in Guanzi tanyuan 管子探源 [Explorations into the Origins of The Master Guan], ed. Luo Genze 羅根澤 (Shanghai: Zhonghua Shuju, 1931), appendix 2; Gu Jiguang 谷䨍光, “Zhanguo Qin Han zhong nong yi shang zhi lilun yu shiji” 戰國秦 漢重農抑商之理論與實際 [“The Theory and Practice of Promoting Agriculture and Suppressing Trade during the Warring States, Qin and Han periods"], Zhongguo shehui jingji shi jikan 中國社會經濟史集刊 [Collected Papers in Chinese Socio-Economic History] 7 (1944): 1-22; Hu Jichuang 胡寄窗, Zhongguo jingji sixiang shi jianbian 中国经 济思想史简编 [A Concise History of Economic Thought in China] (Beijing: Zhongguo Shehui Kexue Chubanshe, 1981): 6.

18 Overgeneralized versions of this thesis continue to appear. See e.g. Jean Levi's introduction to his translation of the Yantie lun. Levi speaks of anti-mercantilism as typifying the entire Chinese tradition, across periods and schools of thought. See Jean Levi, Dispute sur le sel et le fer (Paris: Les Belles Lettres, 2010): 39; or Liang Cai 亮蔡, Witchcraft and the Rise of the Confucian Empire (Albany: State University of New York Press, 2014): 20-21. A still useful, albeit mostly descriptive, outline of economic thought and its main proponents during the period under discussion is Han Fuzhi 韓復智, Liang Han de jingji sixiang 兩漢的經濟思想 [Economic Thought during the Former and Later Han] (Taipei: Taiwan Shangwu Yinshuguan, 1969): 1-117.

19 Michael Loewe, The Government of the Qin and Han Empires (Indianapolis: Hackett, 2006): 157-58. The Guanzi's 管子 “Chi mi” 侈靡 chapter (35) exemplifies the idea of stimulating production through consumption. See W. Allyn Rickett, Guanzi. Political, Economic, and Philosophical Essays from Early China, vol. 2 (Princeton: Princeton University Press, 1998): 292-336. 
Loewe emphasizes that our picture emerges mostly from official writings, and secondly, that a simple dichotomy between commerce and agriculture was never on the agenda. There were, he points out, "different shades of opinion." 20

In this essay I hope to flesh out these shades of opinion in more detail by revisiting some of the arguments put forward by the main proponents, observers and ideologues of Western Han economic policy. I start from the premise that the more strongly court advisors insisted on the primacy of agriculture, the more likely it was that, in reality, mercantile agrarianism was the norm. Han administrators and theorists were coming to grips with a society that required new ideas on wealth creation and wealth management. Few had as yet acquired the skills and language needed to probe beneath the surface of a (political) economy that had become more market-oriented and monetized, and that witnessed increasing technical and professional specialization. Debates about "the economic" in Western Han were often couched in moral abstractions. ${ }^{21}$ The notion that farming and commerce were mutually opposing forces was a recurrent trope in economic discourse, yet behind this perceived dichotomy between grain and goods, other political motifs were at play. I will argue that, for both agriculturalists and those who favoured trade, the real focus of the argument was on government control rather than economic innovation. Assessments of how the professions could contribute to the economy were not so much concerned with how wealth should be generated, or whether or not the pursuit of profit was a noble and productive or an immoral and destructive undertaking. Instead, at stake was the command economy: which economic mechanisms lend themselves best to political and social control? The realm of goods and people, and their flow, as it presented itself to those in power at the court, was a world entirely in the service of the ideal of tight political control.

To be sure, economic thought and ideology as formulated in official sources can only represent a partial picture. Manuscript evidence uncovered in recent decades has helped throw more light on quantitative economic developments

$20 \quad$ Michael Loewe, "Attempts at Economic Co-ordination during the Western Han Dynasty." In The Scope of State Power in China, ed. Stuart R. Schram (Hong Kong: Chinese University of Hong Kong Press, 1985): 258.

21 I borrow the term "the economic" from Rebecca E. Karl's collection of essays to refer to economic thought as a concept of abstraction that often (partly) evolves as an ahistorical absolute and operates at the interstice of imagined and historical economic processes. See The Magic of Concepts. History and the Economic in Twentieth-Century China (Durham, NC: Duke University Press, 2017). Tamara T. Chin's work underscores the value of studying Han economics as a complex imaginary that draws on historiographical, literary and material discourse and practices. See Savage Exchange. Han Imperialism, Chinese Literary Style, and the Economic Imagination (Cambridge, MA: Harvard University Press, 2014). 
and the management of resources in localities. ${ }^{22}$ Nevertheless our understanding of the role of the state in economic matters remains precarious. ${ }^{23}$ We have at hand a record of recommendations, monopolies, laws, and prescriptions but it is difficult to ascertain how effective these court-driven initiatives were in reality. ${ }^{24} \mathrm{On}$ balance historians today agree that the so-called anti-mercantile turn in mid-Western Han did not materialize. As Nishijima Sadao 西嶋定生 pointed out: "Paradoxically, the power of merchants grew even as ever greater efforts were made to repress them." 25 The large-scale circulation of money boosted the rise of merchants who could invest cash in land. Landowning families ran commercial activities even though they may not officially have been recognized as merchants. All this suggests a significant distance between court rhetoric and economic reality. It presents us with a reminder that, when

22 This is reflected in a wave of recent Chinese scholarship that is dominated by statistics. See e.g. Chen Ying 陈英, Handai pin fu chaju yu zhengfu kongzhi yanjiu 汉代贫富差距 与政府控制研究 [A Study of Wealth Disparity and Government Control during the Han Dynasty] (Beijing: Zhongguo Shehui Kexue Chubanshe, 2010); Yu Kunqi 于琨奇, Zhanguo Qin Han xiao nong jingji yanjiu 战国秦汉小农经济研究 [A Study of the Small-Scale Farming Economy during the Warring States, Qin and Han Periods] (Beijing: Shangwu Yinshuguan, 2012); Ding Bangyou 丁邦友, Handai wu jia xin tan 汉代物价新探 [A New Discussion of Commodity Prices during the Han] (Beijing: Zhongguo Shehui Kexue Chubanshe, 2009); Ding Bangyou and Wei Xiaoming 魏晓明, Qin Han wu jia shiliao huishi 秦汉物价史料汇释 [Explanatory Collection of Historical Materials on Qin and Han Commodity Prices] (Beijing: Zhongguo Shehui Kexueyuan Chubanshe, 2016).

23 I am reminded of Michael Loewe's comments three decades ago on the limitations of trying to conceive of an "economic role of the state" for the period in question: "The adoption of an economic role implies a determination of priorities, a conscious decision of the extent to which economic motives should take precedence over other considerations of a moral or religious nature. Such a role would also imply a state's assumption of responsibility for the material well-being of its population and the provision of its necessities; and it would be necessary to formulate criteria for such prosperity that are not contradictory. [...] In practical terms, an economic role depends on a sense of system sufficient to formulate comprehensive policies, and the ability to impose long-term, and probably unpopular, decisions, and to survive the consequent short-term disadvantages and disaffection." See Loewe, "Attempts at Economic Co-ordination during the Western Han Dynasty," 238-9.

24 It is noteworthy that, despite these anti-mercantile measures, legal texts, most notably the Zhangjiashan 張家山 materials (186 BCE), do not echo these negative attitudes towards merchants as a profession. To be sure, these statutes include rules on proper trading, taxation, quality control of goods, etc. but they do not seem to be formulated ex negativo or as discriminatory to a perceived professional group. In fact, prohibitions apply equally to farming folk and their activities.

25 "The Economic and Social History of Former Han." In The Cambridge History of China. Volume I: The Ch'in and Han Empires, 221 B.C.-A.D. 220, ed. Michael Loewe (Cambridge: Cambridge University Press, 1986): 576-8 (quote p. 577). 
reading official sources, it is appropriate not to emphasize the economic over the political. As far as the Han court was concerned, few questioned the ethics of how wealth should be generated as long as political control could be maintained and the government was its main beneficiary.

The most outspoken advocacy of agriculture in the early decades of Han came through the voice of the short-lived, Luoyang-born Jia Yi 賈誼 (201-169 вCE). Jia Yi persuades emperor Wendi (r. 180-157 BCE) to declare agriculture a root profession (nong tianxia zhi ben 農天下之本), and to revive the imperial ploughing ceremony. He further proposes to abolish tax on land and agricultural produce. ${ }^{26}$ Ban Gu introduces Jia Yi's memorial by stating that "Since [Wendi's] era was close to the Zhanguo period, people had all turned their backs on the fundamental occupations and hastened to the secondary ones" (時民近戰國, 皆背本趨末). ${ }^{27}$ Ban Gu depicts Jia Yi's stance as contemporary in that, in his memorial, with the exception of a token reference to the efficient management of food supplies by the ancients, Jia Yi does not overtly associate "agriculturalism" with the pre-imperial past or indeed Qin. Ban Gu's Jia Yi seems to suggest that the need to prioritize agriculture constitutes a break with the immediate past. The premise is that the Warring States had not upheld the separation of the professions and allowed them to undermine each other. Noteworthy too is that, for all the venom in Jia Yi's famous essay laying out the faults of Qin (“Guo Qin lun” 過秦論), he makes little or no reference to agriculture or Qin economics. ${ }^{28}$ By contrast, in the Xinshu 新書, Jia Yi is cast as someone with a keener eye for historical cycles. There he makes reference to an idealized past when speaking of a model crop return and storage pattern associated with the former kings. He also intimates that focusing on farming does constitute some sort of "return" (gui 歸) to a moment in the past. ${ }^{29}$

26 Hanshu, 24A.1127-30; Shiji, 10.428; Xinshu jiaozhu 新書校注 [Annotated commentary to New Writings], ed. Yan Zhenyi 閻振益 and Zhong Xia 鍾夏 (Beijing: Zhonghua Shuju, 2000), 3.103 (“Gui wei” 瑰瑋); Hsu Cho-yun 許倬雲, Han Agriculture. The Formation of Early Chinese Agrarian Economy (206 B.C.-A.D. 220) (Seattle and London: University of Washington Press, 1980): 158-60.

27 Hanshu, 24A.1127.

28 With the exception that he notes that Chen She 陳涉, who rebelled against the Qin, was a man of humble origin who "rose up from the paths of the fields." See Shiji, 6.281.

29 Xinshu jiaozhu, 3.124 ("You min"), 4.164 (“Wu xu"), 6.216-217 ("Li"). While it remains uncertain whether the received Xinshu, especially those parts that do not have equivalents in Sima Qian and Ban Gu's histories, came from the hands of Jia Yi himself, or from his 
In Jia Yi's analysis wealth (cai 財) equals grain ( $s u$ 粟). Allowing people to cast copper money lures them away from the fields. ${ }^{30}$ The storage of grain ahead of bad times is the "great lifeline" (da ming 大命) of empire, and agriculture is the best guarantee for social order:

\section{夫積貯者, 天下之大命也。苟粟多而財有餘, 何為而不成 [...] 今毆民 而歸之農, 皆著於本, 使天下各食其力, 末技游食之民轉而緣南畧, 則畜積足而人樂其所矣。可以為富安天下 $[. .$.}

As for the accumulation of supplies, it is the great lifeline of the world. If grain is abundant and there are ample material resources, what cannot be accomplished if attempted? [...] Now may your Majesty drive the people to return to farming, so that all will stick to the fundamentals, and cause everyone under Heaven to feed oneself from one's own labour, so that all those who work at secondary occupations ${ }^{31}$ and those who wander from place to place without a secure means of livelihood will turn around and follow the road to the "southern acres". Then the accumulation of supplies will be sufficient and the people will find joy in their station. Thus wealth can be created and the world can be kept at peace. ${ }^{32}$

The emphasis is on social order and political control. Autarky and selfsufficiency are to be forced ( $q u$ 毆) upon the people. ${ }^{33}$ In the longer Xinshu

followers or students, there are good arguments in favour of its validity as a Han text. See Rune Svarverud, Methods of the Way: Early Chinese Ethical Thought (Leiden: E.J. Brill, 1998): 1-154; Michael Nylan, "Hsin shu." In Michael Loewe ed., Early Chinese Texts. A Bibliographical Guide (Berkeley: The Society for the Study of Early China and The Institute of East Asian Studies, 1993): 166-8.

$30 \quad$ Xinshujiaozhu, 3.110-111 ("Tong bu"), 4.167 ("Zhu qian").

31 Wu Song 吴松 suggests that, by late Warring States times, mo was no longer a general denominator for peripheral or non-essential activities but became exclusively synonymous with trade and crafts. See Wu Song 吴松, Zhongguo nong shang guanxi sixiang shigang 中国农商关系思想史纲 [An Outline of the Relationship between Agriculture and Commerce in the History of Chinese Thought] (Kunming: Yunnan Daxue Chubanshe, 2000): 87-91, 98. I am unconvinced that narrowing down these terms chronologically to singular meanings is supported by the sources.

32 Hanshu, 24A.113o; cf. Nancy Lee Swann, Food and Money in Ancient China (Princeton: Princeton University Press, 1950): 156-7; Xinshu jiaozhu, 3.103, 4.163; Hsu Cho-yun, Han Agriculture: 159. "Southern acres" (nan mou 南畧) is an allusion to a line in an ode in the Shijing [Book of Odes] ("Da tian" 大田, Mao 212) describing agricultural work and sacrifices connected to it. See Maoshi zhengyi 毛詩正義 [The Correct Meanings of the Mao Edition of The Odes], Shisanjing zhushu edition, vol. 2: 14A.13b. Over time it became a general expression for taking to the fields.

33 Autarky is not an inescapable model or condition forced upon people in pre-industrial societies, the market being the obvious example of how, in the pre-modern world, 
version of the memorial the idea of people complying and finding peace with their lot is articulated more verbosely. There the text states that if people are devoted to agriculture

則民安性勸業而無懸薇之心, 無荷得之志, 行恭儉蓄積而人樂其所. 故 曰: 苦民而民益樂.

their nature will be at ease, they will be fully dedicated to their job, they won't have a mind to overstep the mark or be bent on illicit gains. Their conduct will be respectful and frugal, and their supplies will accumulate, and they will be happy in their station. Therefore, it is said that if you work the people hard, they will be increasingly happy. ${ }^{34}$

Jia Yi's arguments sit within his wider agenda to strengthen the economic fibres of empire against internal pressures from rebellious kingdoms and, more importantly, external threats posed by the Xiongnu state. By Wendi's time the Xiongnu were a well-oiled confederacy posing a constant military threat to Han's northern borders. ${ }^{35}$ For Jia Yi, grain is the basic marker of wealth (and hence peace). Yet, while emphasizing the importance of grain, he invests little or no thought in how to promote agriculture other than by rule of force. Much

production, exchange and consumption could be undertaken by different actors. There would simply be no reference to markets in early China unless the exchange of agricultural produce was partly marketized. In addition, self-sufficiency as a concept, in early China as elsewhere, manifests itself in different shades (and notions of sufficiency can be subject to societal norms). The best evidence for this in early China are the ideas associated with the so-called Tillers (Nong jia 農家), who appear in snippets across several Warring States masters texts, most notably in a famous exchange in Mencius 3A.4. See Angus Graham, "The Nung-chia 'School of Tillers' and the Origins of Peasant Utopianism in China." Bulletin of the School of Oriental and African Studies 42/1 (1979): 66-10o.

34 Xinshujiaozhu, 3.103.

35 Dislocated people could be recruited away from the fields by the feudatories, while Xiongnu pressures called for the mobilisation of armies at the expense of the available labour force. Jia Yi and Chao Cuo's Xiongnu strategies are discussed in Nicola Di Cosmo, Ancient China and its Enemies. The Rise of Nomadic Power in East Asian History (Cambridge: Cambridge University Press, 2002): 201-5; and Elisa Levi Sabattini, "War economy during the Western Han." In The Political Economy of the Han Dynasty and Its Legacy, ed. Cheng Lin, Terry Peach and Wang Fang (London and New York: Routledge, 2019): chapter 7. Payments and diplomacy sustained a tenuous peace during the first few decades of the Han until, starting in 134 BCE, Han Wudi embarked on pro-active military campaigns against the nomad empire venturing deep into Central Asia. For a succinct overview see Yü Ying-shih, "Han Foreign Relations." In Michael Loewe ed., The Cambridge History of China. Volume I:The Ch'in and Han Empires, 221 B.C.-A.D. 220:383-40o; and Mark Edward Lewis, The Early Chinese Empires. Qin and Han (Cambridge, MA: The Bellknapp Press of Harvard University Press, 2007): 129-41. 
of his thinking is formulated in a language of moral abstraction. Securing compliant behaviour among the populace emerges as the aim and natural outcome of agriculturalist policy. "Delighting in one’s station" (le qi suo 樂其所) is presented as a positive consequence of toil and tough grind. A concern with the laws of productivity or what types of agricultural work could best achieve this seems secondary.

More radical than Jia Yi in his conviction that the grain economy should be at the heart of society, was Chao Cuo 沓錯 (d. 154 BCE). Chao Cuo's Shiji biography reveals little about his theories other than that he studied the teachings of Shen Buhai 申不害 (c. 40O-c. 34 O BCE) and Shang Yang 商鞅 (d. 338 BCE). ${ }^{36}$ Chao Cuo sees the promotion of agriculture as a way to encourage the settlement of people (he envisaged revenue-generating military-agricultural settlements along the empire's frontiers). In that sense he draws on the pre-Qin legalists who saw the stimulus of agriculture as a means to strengthen the state through the service of farmer-soldiers. ${ }^{37}$ In 178 вС E Chao Cuo swayed Wendi to grant ranks and redeem crimes in return for contributions of grain to the state's granaries. ${ }^{38}$ Whereas Jia Yi stressed self-sufficiency and the prevention of population movement, Chao Cuo emphasizes the role of the ruler as a facilitator. He does so by referring to the sage kings of antiquity (Yao 堯, Yu 禹, Tang 湯) who were able to stave off cyclical floods and droughts by building up reserves in times of plenty. Rulers do not necessarily feed and clothe the people themselves: they see it as their role to "open up the way towards means and resources” for the people (為開其資材之道也). ${ }^{39}$ Underdeveloped agriculture, inadequate exploitation of natural resources, and a floating population all contribute to shortages. Most importantly, to be avoided at all cost is underused or untapped potential among the labour force (min you yu li 民有餘力). ${ }^{40}$

36 Shiji, 101.2745 .

37 For Chao Cuo's memorial see Hanshu, 24A.1130-4. On the role of agriculture versus commerce in the Shangjun shu and Han Feizi 韓非子, see Sterckx, "Ideologies of the peasant and merchant.": 217-23, 233-5.

38 The need to reward merchants for carting grain over long distances suggests that transporting perishable goods may not have been such a profitable trade after all. Generally, grain and staples did not rank high as a trading commodity associated with merchants. Possibly commercial transactions in grain also did not carry the same moral baggage as did the trading of commodities and luxury goods, utilities, and other valuables.

39 Hanshu, 24A.1130.

40 Hanshu, 24A.1131. 
The origins of poverty then are linked to a lack of agricultural and sericultural production:

民貧則姦邪生。貧生於不足, 不足生於不農, 不農則不地著, 不地 著則離鄉輕家, 民如鳥獸, 雖有高城深池, 嚴法重刑, 猶不能禁 也。 $[\ldots]$

If people are poor, then licentiousness and depravity follow. Poverty is born from insufficiency; insufficiency originates in not farming. If the people do not farm, they will not stick to the land. If they do not stick to the land, then they will leave their native places and regard their families lightly. The people would be like birds and beasts. Even if there were high city walls, deep moats, severe laws and heavy punishments, it would still be impossible to restrain them. ${ }^{41}$

Hunger and cold, Chao Cuo continues, undermine all attempts to gain the loyalty of one's people. For the ruler, grain and textiles therefore should be more valuable and expedient an asset than precious metals and stones could be. The farmer's hard grind however stands in stark contrast to the comfortable existence of those who live off trade, even though the law is meant to make it harder for merchants:

今法律賤商人, 商人已富貴矣; 尊農夫, 農夫已貧賤矣。故俗之所 貴，主之所賤也；吏之所卑，法之所尊也。

Now, the laws and regulations despise merchants, but the merchants have already become rich and noble; the law esteems peasants, but the peasants have already become poor and debased. Therefore, what is esteemed by custom is looked down upon by the ruler and what is despised by officials is honoured by the law $[\ldots] .{ }^{42}$

Note how Chao Cuo pitches $s u$ 俗 versus $f a$ 法, or, to quote Ch'ü T'ung-tsu, social esteem versus legal status. ${ }^{43}$ There is a disjuncture between the ideology and interests of the government and the social capital generated by those who

41 Hanshu, 24A.1131. Elsewhere Chao Cuo links the image of foraging birds and beasts to nomadism (erroneously implying that steppe nomads did not engage in agriculture or could not subsist in fortified settlements). See Hanshu, 49.2285. Sima Qian makes a similar point, see Shiji, 110.2879 .

42 Hanshu, 24A.1133.

43 Ch'ü T'ung-tsu, Han Social Structure: 111. 
enrich themselves through trade. The only way to redress this imbalance is by inflating the social value of grains and textiles:

今之務, 莫若使民務農而已矣。欲民務農, 在於貴粟; 貴粟之道, 在 於使民以粟為賞罰。[… 神農之教曰: 「有石城十仞, 湯池百步, 帶甲 百萬, 而亡粟, 弗能守也。」

There is no more important task for today than to make people devote themselves to farming. If we wish the people to devote themselves to farming, we must make grain more valuable. The way to make grain more valuable is to allow the people to use grain to gain rewards or redeem punishments. [...] The teachings of Shennong say: 'Even though there be a stone city wall ten ren (fifty-six Han feet) high, a moat of boiling water a hundred paces wide, and a million soldiers, if one neglects grain there can be no defence of it. ${ }^{44}$

Thus farming was to be the fundamental source of productivity. Yet farmers were poor and hence looked-down upon, especially those who owned sub-sized plots or no land at all. Merchants, by contrast, were deemed nonproductive and discriminated against in sumptuary law. Nevertheless, their wealth earned them respect and status.

Note that Chao Cuo's plea "to make grain valuable" is only partly concerned with its production. Instead, it is seen first and foremost as a mechanism to ensure that people "stick to the land". At the heart of his thinking is the political control of a population: unlike grain and cloth, precious stones and metals, as objects, do not directly alleviate hunger or cold yet, when used as currency or barter, they grant individuals the economic independence that allows them to abandon one's village and travel around the empire without anxiety about cold and hunger. The implication here is that fear of hunger and the threat of poverty is de facto an expedient tool for a ruler:

民者, 在上所以牧之, 趨利如水走下, 四方亡擇也。[...]粟米布帛生於 地, 長於時, 聚於力, 非可一日成也; 數石之重, 中人弗勝, 不為姦 邪所利 $[\ldots]$ 。

The [attitude of the] people depends on the methods by which the ruler shepherds them, for they rush towards profit just as water runs

44 Hanshu, 24A.1133; Swann, Food and Money: 159, 166, 168; Hsu Cho-yun, Han Agriculture: 16o-3. 
downwards and they do not have any preferences into which of the four directions they go [...] Grain and cloth and silk are produced by the land, mature with the season, and are gathered together by means of physical labour. ${ }^{45}$ All this cannot be accomplished in one day. [Grain or cloth] weighing several piculs cannot be moved by the average man and are not profitable to those who are dishonest. $[\ldots]^{46}$

In short, Chao Cuo's claim that the "grain (economy) is the greatest utility of a ruler and the fundamental task in government” (粟者, 王者大用, 政之本務) is a political claim first and, only secondarily, an economic assessment. Agriculture is the key to political landscaping and coercion. Tying the population to the land (as if planting and "rooting" them into the soil) is the best guarantee to enforce loyalty to native region and family. In extremis, Chao Cuo's strategy simply reflects the realities of bulk transport: goods that draw their value largely from volume will prevent the random and unregistered circulation of people.

\section{Holding Land}

A third prominent voice commenting on the fate of the farmer was Dong Zhongshu 懂仲舒 (ca. 179-ca. 104 BCE). Yet, unlike Jia Yi and Chao Cuo, who drew attention to farming as the most efficient means to control a population, Dong zooms in on the issue of landownership. ${ }^{47}$ In his memorial (submitted

45 Both Swann and Hsu follow an emendation of 市 for 力 "gathered together and brought to market". I do not think this is necessary. As I read it, the emphasis here is on the physicality of farm labour. Grammatically the use of 於 seems entirely parallel here.

46 Hanshu, 24A.1131-2; Hsu Cho-yun, Han Agriculture: 161; Swann, Food and Money: 161.

47 The issue of ownership, public or private, is complex. Land could be held in different ways: in addition to fields registered in an individual's name (ming tian 名田), public fields (gong tian 公田) could be given in ownership by the emperor. Land could be granted as part of a rank of honour (jue 爵) that was awarded, it could be acquired by purchase or could be reclaimed. All non-agricultural land and natural resources (mountains, marshes, forests, waterways, parks, etc.) were in principle the emperor's private property. They were managed by the Privy Treasurer (shaofu 少府) and not a source of revenue for the Grand Minister of Agriculture (Da sinong 大司農), who was the government's treasurer. See Shiji, 30.1418; Hanshu, 24A.1127; Swann, Food and Money: 150-1. In 205 BCE, an edict went out that permitted land formerly used for imperial zoos, parks, gardens and ponds to be cultivated; see Hanshu, 1A.33; Hsu Cho-yun, Han Agriculture: 172 (no. 25). The government would be criticized later that only powerful families benefited from this. See Yantie lun jiaozhu, 13.172 ("Yuan chi"). The court could show largesse in times of need or natural disasters by opening up these resources to the public. E.g. in 140 BCE horse 
ca $100 \mathrm{BCE}),{ }^{48}$ Dong imagines pre-Qin times as an age of fair labour and fair taxation, condemns the Qin land reforms and the transaction (mai mai 賣買) and privatization of land as a main cause of deprivation, and expresses the desire to go back to the ideal of communal labour on "well-fields" (jing tian 井田). ${ }^{49}$ Inscribing his views into the past, Dong invokes the Chunqiu 春秋 [Spring and Autumn Annals] in order to criticize the neglect of wheat sowing. For Dong the Qin agrarian reforms, and the ensuing situation in early Western Han, are unfortunate interludes. He speaks of ancient times as a period of equitable levies and corvée obligations, when "people had the wealth to nourish their parents in order to fulfil the duty of filial piety, to serve the ruler by paying tax, and to support wife and children with utmost affection” (民財內足以養 老盡孝, 外足以事上共稅, 下足以畜妻子極愛). ${ }^{50}$ People in the past therefore “delighted in following their rulers (民說從上).” Dong condemns the abolition of the well-field system and the land reforms of Shang Yang. Poverty had been aggravated, Dong argues, by increased taxes, up twentyfold from ancient times, with corvée labour augmented to one month per annum. Then there was the obligation of farmers to be conscripted and serve in frontier garrisons, to pay increased land tax, ${ }^{51}$ poll tax, salt and iron taxes, and so on. Poor farmers had

pastures were given to the poor (Hanshu, 6.157; Hsu Cho-yun, Han Agriculture: 177); or in 78 вСE the imperial park of Zhongmou 中牟 was divided up among the poor (Hanshu, 8.229; Hsu Cho-yun, Han Agriculture: 178). More examples of water reservoirs, lands and parks being distributed or let are collated in Hsu Cho-yun, Han Agriculture: 178-80.

48 Michael Loewe questions Swann's dating of ca. 100 вCE for these statements but acknowledges there is little in the form of hard evidence linked to concrete policies to settle on a more fixed date, other perhaps than the possibility that merchants, up to ca. $119 \mathrm{BCE}$, may have been able to purchase land in their own name (ming tian 名田). See Michael Loewe, Dong Zhongshu, a 'Confucian' Heritage and the Chunqiu fanlu (Leiden: Brill, 2011), 101-4.

49 The "well-field" is first described in Mencius 3A.3. Envisaged is a community organized on land shaped like a grid with eight squares that surround a ninth in the center (mimicking the graph jing 井). Eight individual families work their own plot while their overlord receives the income from the ninth (central) plot that is tilled communally. Its historicity is highly doubtful. See Sterckx, "Ideologies of the peasant and merchant": 216-8; and Tamara T. Chin, Savage Exchange: 58-9. Gu Yanwu 顧炎武 (1613-1682) idealized it as follows: "In drawing up the well-field system and demarcating the fields, [the former kings] joined what was private in the world to perfect what was public. This is why it is considered to have been a kingly administration." See Ri zhi lu 日知錄 [Record of Daily Knowledge, 1695] as in Ian Johnston tr., Record of Daily Knowledge and Collected Poems and Essays: Selections (New York: Columbia University Press, 2017): 54.

50 Hanshu, 24A.1137.

51 Hanshu, 24A.1137. Dong suggests one in ten as the ideal tax ratio. Land taxes varied through Western Han, ranging from $1 / 10$ th and $1 / 15^{\text {th }}$ under Gaozu and Huidi to periods of $1 / 3$ oth under Wendi. No exact percentage figure is attested yet for the pre-imperial Qin state. See Yu Kunqi, Zhanguo Qin Han xiao nong jingji yanjiu: 92-10o. Estimating tax returns from 
been forced to give up nearly half of their yield as rent to wealthy landowners. Since Han emperors had been unable to reverse agrarian hardship, Dong wants to see an institution that is somewhat closer to the ancient system:

\section{古井田法雖難卒行, 宜少近古, 限民名田, 以澹不足, 塞并兼之路.}

Although it is impossible to put into practice entirely the old well-field system, it is appropriate that we more or less come close to antiquity, and limit the appropriation of land by private people so as to sustain those who are in want and block the path to land monopolies. ${ }^{52}$

Inasmuch as Dong Zhongshu puts his finger with force of persuasion on some of the causes of agricultural decline, it is striking that his remedy to address the problems consists merely of reducing taxes and a faint hope that the golden age of the well-field system will bring reprieve to the farmer's lot. ${ }^{53}$ Dong and the policy advisors reviewed so far do not delve beyond land reform, the abandonment of the farming profession, or the issues of currency as causes for the harsh economic predicament of the workforce. By doing this, they sidestep arguments that could potentially be positive to the fate of the labour force but would be at odds with the interests of the court. Behind descriptions of the toilsome nature of farm labour and the recurrent reminder that such work should occupy one's entire being and time, there lurks an acknowledgement

land is complicated by several factors: the mou changed size as a surface measurement and grain productivity depended on the quality, fertility and location of the land. In addition the context in which figures are reported may have played a role. Officials pleading on behalf of the poor were likely to use bottom line figures whereas officials reporting on tax returns may have been guilty of inflating figures. Chen Ying points out that Chao Cuo's projected yields per surface unit are consistently lower than those proposed by Li Kui 李 愧 (fl. 445 BCE) in Zhanguo times. See Chen Ying, Handai pin fu chaju yu zhengfu kongzhi yanjiu: 46-7. Some estimates put the acreage available per registered small farming household at around sixty-seven $m u$ at the time of the census of $2 \mathrm{CE}$ (one mu equalling around o.11 acre). In reality, it may have averaged much lower to around fifty mu. See Yu Kunqi, Zhanguo Qin Han xiao nong jingji yanjiu: 130-5, 147-8; Chen Ying, Handai pin fu chaju yu zhengfu kongzhi yanjiu: 65 .

$5^{2}$ Hanshu, 24A.1137; Hsu Cho-yun, Han Agriculture: 163-4.

53 Another similar reflection on the utopian bliss of the well-fields occurs in the Han shi waizhuan 韓詩外傳, attributed to Han Ying 韓嬰 (fl. 150 BCE). See Han shi waizhuan jishi 韓詩外傳集釋 [Collected Explanatory Commentaries on Han Ying's Illustrations of the Didactic Application of the Book of Songs], ed. Xu Weiyu 許維逼 (Beijing: Zhonghua Shuju, 1980): 4.143-44. It speaks of farmers protecting one another (xiang bao 相保), holding watch in turn over each other's movements (chu ru geng shou 出入更守), sharing anxieties in ill health, loaning to the needy, etc. 
that rulers benefit from a population whose energies and interests cannot be directed elsewhere. Anathema in this context is the idea that technological efficiencies and agronomic advances, rather than peasant numbers, could increase yields, or the notion that more intensive farming would free up some to concentrate on other economic tasks. Controlling the population in their station seems the main motive.

In his chapter on the commodity producers ("Huozhi liezhuan" 貨殖列傳; Shiji, chapter 129), ${ }^{54}$ Sima Qian (or, more accurately, his authorial persona created in Shiji) refrains from setting up agriculture and mercantile culture as mutually opposing spheres. Instead he is explicit in acknowledging that it is more beneficial to run them in tandem. Yet, Sima Qian is adamant that one should prevent certain trades from being monopolized by government. As Hans van Ess observes, he is positive towards merchants, as long as they do not also operate as officials. ${ }^{55}$

Sima Qian does not question commerce as a justified source of wealth creation, but he attacks the imperial centre and bureaucracy for wanting to take direct control of the process. There is strong emphasis on human beings'

54 Michael Nylan translates, "assets accumulating” 貨殖. Cf. Nylan, "Assets Accumulating: Sima Qian's Perspective on Moneymaking, Virtue, and History." In Views from Within, Views from Beyond: Approaches to the Shiji as an early work of historiography, ed. Hans van Ess, Olga Lomová, and Dorothee Schaab-Hanke (Wiesbaden: Harrassowitz Verlag, 2015): 131-68.

55 See van Ess, Politik und Geschichtsschreibung, vol. 2: 6o3, 615-16, who argues that Sima Qian is more liberal in that he suggests that wealth creation ultimately will lead to the greater good of all; Ban Gu by contrast is more protectionist in that he feels rules and regulations are necessary to ensure that the search for profit does not lead to ruin. The Hanshu biography of Sima Qian is critical of his pro-mercantile stance: "When describing the biographies of the moneymakers [Sima Qian] admires power and profit and disdains lowliness and poverty (述貨殖則崇勢利而羞賤貧). See Hanshu, 62.2738. Yang Xiong 揚雄 (53 BCE-18 CE) also takes issue with the moneymakers (huo zhi 貨殖), whom he labels as mere mosquitos (wen 蚊): "I say they sucked the blood of thousands of states. And if only they lived frugally, picking wild greens to eat, drinking plain water, and wearing the simplest clothes, they would have sparked no resentment to the end of their days (曰血國三千, 使捋疏、飲水、褐博, 沒齒無愁也).” See Fa yan (tr. Michael Nylan, Exemplary Figures [Seattle and London: University of Washington Press, 2013]): 195 (11.17). On the possible influence of Fayan in forging the image of merchants, see Béatrice L'Haridon, "The Merchants in Shiji: An Interpretation in the Light of Later Debates." In Hans van Ess et al. ed., Views from Within, Views from Beyond: 176-8, 184-7. 
autonomous capacity to fulfil their potential (ren ge ren qineng 人各任其能). If left to their own devices, people are sufficiently creative to make a living without government directives. ${ }^{56} \mathrm{He}$ quotes a lost passage from the "Book of Zhou" (Zhou shu 周書) to identify farmers, craftsmen, merchants and foresters (but not scholars) as the four essential pillars of the economy:

農不出則乏其食, 工不出則乏其事, 商不出則三寶絕, 虞不出則財匱 少, 財匱少而山澤不辟矣。此四者, 民所衣食之原也.

If farmers do not produce, there will be a shortage of food; if artisans do not produce, there will be a shortage of manufactured goods; if merchants do not produce, then the three precious things will not circulate; if foresters do not produce, there will be a shortage of natural resources; and if there is a shortage of wealth, the resources of the mountains and lakes cannot be exploited. These four classes are the source of people's clothing and food. ${ }^{57}$

Sima Qian is subtle in the way he dethrones agriculture as the only gateway to wealth, and, at times, his arguments are couched in a delicate, almost agricultural and calendrical language. For instance in his account of Bai Gui 白圭 (fourth century BCE), who defied old-style agriculturalist advice by Li Ke 李克 to exploit the powers of the soil, Sima Qian notes how Bai Gui "delighted in observing the changes of the times" (le guan shi bian 樂觀時變), “took what others threw away, and gave away what others took" (ren qi wo qu, ren qu wo yu 人弃我取, 人取我與). Bai Gui bought up grain in times of plenty in return for silk and lacquer, and he sold grain to buy up silk when the market was good. Observing the seasons, reading the stars and gauging the weather cycles appear as skills that are as essential to the merchant as they are to the farmer.

56 Shiji, 129.3254. The re-evaluation of trade next to agriculture in Sima Qian is the main argument in Hui Fuping 惠富平, Shiji yu Zhongguo nongye 史记与中国农业 [The Historical Records and Chinese Agriculture] (Xian: Shaanxi Renmin Chubanshe, 200o): 162-7o. Nie Shiqiao 聂石樵 summarizes Sima Qian's position rather simplistically as follows: "wealth does not come about because someone has given it to you, nor does poverty arise because someone has taken something away from you, both depend entirely on people's intelligence or stupidity." See Nie Shiqiao 聂石樵, Sima Qian lungao 司马迁论稿 [Essays on Sima Qian] (Beijing: Zhonghua Shuju, 2010): 177.

57 Shiji, 129.3255. Yu 虞 are not foresters in a strict sense but officers who oversee the exploitation of natural resources (including fishing, mining, etc). The san bao "three treasures" refers to agricultural produce, manufactured goods, and produce from lakes, mountains, parks, etc. The reference to "Zhou writings" may be linked to the Yi Zhoushu. See Nylan, “Assets Accumulating": 149 n. $5^{8}$. 
The key is to balance changing circumstances to one's advantage (quan bian 權變).58 Sima Qian praises the people living on the former territories of Lu and Qi for having the air of a great state (da guo zhifeng 大國之風) because all the professions are represented among them. ${ }^{59}$ Despite his pro-mercantile position, agriculture remains, albeit subtly, infused with moral superiority. Hence the people living on the former territories of Lu and Qi are said to be intelligent and fond of debate, which goes hand in hand with their inclination to attach great importance to the land (implying they stay stationary) and to dislike turmoil. ${ }^{60}$ The inhabitants of the old states of Liang and Song are said to perpetuate the demeanour and lingering influence of former kings, value the presence of a large number of gentlemen, and devote themselves to agricultural pursuits. ${ }^{61}$

And so, rhetorically at least, Sima Qian upholds farming as the noblest way to gain a living while acknowledging that, in reality, the secondary occupations offer the fastest way out of poverty:

是故本富為上, 末富次之, 姦富最下.

Therefore the highest form of wealth is that which is based upon agriculture [ben fu 本富], the next best is that which is derived from secondary occupations [mofu 末富], and the worst form of wealth is that which is acquired by evil means [jian fu 姦富]. ${ }^{62}$

However, implicit in the noble and levelling capacity of agriculture is a recognition that farming is the most toilsome road to wealth (as it requires land, time, tools, depends on weather conditions, offers lower returns, etc.):

夫用貧求富, 農不如工, 工不如商, 刺繡文不如倚市門, 此言末業, 貧者之資也。

$5^{8}$ Shiji, 129.3258-9. Bai Gui's methods also receive an honourable mention by the government party in Yantie lun jiaozhu, 17.220 ("Pin fu").

59 Shiji, 129.2365-6. Five classes of people (wu min 五民) are mentioned and listed in commentary by Fu Qian 服虔 (ca. 125-ca. 95 BCE) as scholars, farmers, travelling merchants (shang 商), artisans, and resident traders ( $g u$ 賈).

6o Shiji, 129.3265.

61 Shiji, $129 \cdot 3266$.

62 Shiji, 129.3272. The terms "root wealth", "branch wealth" and "illicit wealth" have been interpreted in different ways and some ambivalence surrounds Sima Qian's introduction of the phrase. See Chin, Savage Exchange, 163-66. Yet, whether one takes it as a simple hierarchy privileging agriculture over commerce and criminality, or as a ranking of risk to those undertaking it, the sequence itself seems in no doubt. 
Thus, if a person is trying to work his way up from poverty to riches, then farming is not as good as handicrafts, and handicrafts are not as good as trade; embroidering ornamental patterns at home is not as good as lounging about the market gate. What I am saying is that the secondary professions are the best sources of wealth for a poor person. ${ }^{63}$

And, thus, lauded as exemplary by Sima Qian are those entrepreneurs who without titles, fiefs, gifts or government salaries, acquired wealth by astute means. For these “untitled nobles" (su feng 素封), moneymaking comes with moral capital. Sima Qian, to quote Tamara Chin, "introduces the 'commodity producer' as the new ethical subject of the market economy." ${ }^{4}$ For the poor and unprivileged, a well-timed and coordinated combination of commerce and agriculture ensures wealth: "one brings about wealth through the branches (commerce) and holds onto it by investing in the roots (agriculture)" (yi mo zhi cai, yong ben shou zhi 以末致財, 用本守之). ${ }^{65}$ Elsewhere Sima Qian accepts the purpose of currency as a necessary means of exchange between farmers and merchants but warns of abuse and manipulation. ${ }^{66}$ Sima Qian presents agriculture and commerce as complementary. Rhetorically, however, he does not disrobe agriculture and landbased productivity of its moral authority. Yet, unlike the dominant view we have encountered so far, Sima Qian wishes to see a lesser role for the state. ${ }^{67}$

While in his chapter on the commodity producers Sima Qian appears largely positive about mercantile knack and success, he is ready to criticize merchants harshly elsewhere in the Shiji and to pour scorn on officials who parted with the sense for generosity displayed by past exemplars. Sima Qian's biography

63 Shiji, $129 \cdot 3274$.

64 Chin, Savage Exchange: 152; Nylan notes: "Wealth is thus only a pre-condition for and erratic emblem of moral action; it is no guarantee of morality. At the same time, moral worth, feigned or real, counts for virtually nothing, if it does not command sufficient wealth to prop it up ... In the long run, virtuous action has a market value, it being the most practical way to accumulate and keep money." See "Assets Accumulating": 157-8.

65 Shiji, 129.3281.

66 Shiji, 30.1442.

67 As Chin puts it, Sima Qian "shifts the moral agent of wealth redistribution from the state to the individual entrepreneur." See Savage Exchange: 153. Vincent S. Leung likewise highlights the futile role of governance and government institutions in the making of these moneymakers. See The Politics of the Past in Early China (Cambridge: Cambridge University Press, 2019): 160-3. 
of Bu Shi 卜式, in Shiji chapter 30, typifies how the historian's preference still veers towards wealth creation that is anchored in agricultural or rural labour, while acknowledging that commerce can be fostered on the back of it. Having depicted merchants as shameles s hoarders and government officials as sharks on several occasions, Sima Qian introduces the figure of Bu Shi, a shepherd in Henan. Bu Shi makes a fortune multiplying his flocks, then selflessly hands over a share of his wealth to his younger brother, who mismanages the family farm while Bu was tending to his herds in the mountains. When Bu Shi offers to turn over half of his wealth to the throne in aid of border defences, Sima Qian depicts him as utterly pure in character, never quarrelling with anyone, and always prepared to share his fortune to relieve the poor in his home region. The man is too good to be true, chancellor Gongsun Hong 公孫弘 warns his emperor, "his proposal [not to keep and conceal but hand over his wealth] is simply not in accord with human nature (ci fei ren qing 此非人情).”68

So Bu Shi is turned down for office and retreats to his pastures. Meanwhile, he continues to accumulate moral credit by handing over large stacks of cash to the governor of Henan. While rich families are scrambling to hide their wealth, Bu Shi offers to contribute to the expenses of government. Han Wudi attempts again to lure him to court, first by assigning him to herd sheep in the Shanglin Park on his straw sandals. As the Shanglin flocks keep multiplying, the emperor spots Bu's potential. At this point in the biography Sima Qian inserts a catchy commentary in the form of a craft analogy coined by Bu Shi:

非獨羊也, 治民亦猶是也。以時起居; 惡者輙斥去, 冊令敗群.

[My success] does not only apply to sheep, governing people also works like this. Get them up at the right time, let them rest at the right time; if there are any bad ones, pull them out at once so that they do not have a chance to spoil the flock. ${ }^{69}$

$\mathrm{Bu}$ Shi's official career is now launched. The shepherd-entrepreneur distinguishes himself from the conventional selfish merchant or landed family. Special levies are issued to dent the fortunes of merchants and wealthy families who made their fortunes through illegal minting. But the emperor realizes, "no other commoners are willing to imitate Bu Shi's example by donating wealth to government officials (百姓終莫分才佐縣官).” ${ }^{70}$ Thus the government

\footnotetext{
68 Shiji, 30.1432.

69 Shiji, 30.1431-2.

70 Shiji, 30.1434. The exact meaning of xianguan, officers subject to the central government but operational in the counties, has been subject to debate. See Michael Loewe, "The
} 
campaign to confiscate private wealth intensifies, as does the implementation of the salt and iron monopolies: "Nearly all merchants of middling or better means were ruined and the people, deciding that they had better indulge in tasty food and fine clothing while they still had the opportunity, made no effort to lay away any wealth for the future" (於是商賈中家以上 大率破, 民偷甘食好衣, 不事畜藏之產業). ${ }^{71}$ When, in 112 BCE, the Southern Yue start a rebellion and $\mathrm{Bu}$ Shi offers to join battle, the emperor issues an edict:

卜式雖躬耕牧, 不以為利, 有餘輯助縣官之用。今天下不幸有急, 而 式奮願父子死之, 雖未戰, 可謂義形於內。

Although Bu Shi in person ploughed the fields and pastured his animals, he did not work for private gain. Whenever he had any surplus, he immediately turned it over to government officials to aid in the expenses of government. Now unfortunately the empire faces this threat from abroad, and Bu Shi, roused to action, has volunteered to go with his sons to die in battle. Although he has never actually taken part in combat, it is obvious that in his heart he bears a true sense of duty. ${ }^{72}$

In the end $\mathrm{Bu}$ Shi turns out to be the only volunteer as all other marquises pass on the opportunity to display selfless bravery in battle for the court. In 110 BCE $\mathrm{Bu}$ Shi is degraded. His rival, Superintendent of Agriculture (Da Sinong 大司 農; and later, Imperial Councillor), Sang Hongyang 桑弘羊 (152-80 BCE), a man of merchant stock, takes over the management of the economy and sets up the "balanced standard" system. Bu Shi, alias Sima Qian, resents this micromanagement of commerce by government officials who, in his view, should merely collect taxes:

今弘羊令吏坐市列肆, 販物求利。亨弘羊, 天乃雨。

But now Sang Hongyang has them sitting in the market stalls buying and selling goods and scrambling for a profit. If your Majesty were to boil Sang Hongyang alive, I think Heaven might send us rain! ${ }^{73}$

organs of Han imperial government: zhongdu guan, duguan, xianguan, and xiandao guan." Bulletin of the School of Oriental and African Studies 71/3 (2008): 519 .

71 Shiji, 30.1435.

72 Shiji, 30.1439.

73 Shiji, 30.1442. Yang Xiong sides with Bu Shi's criticisms of Sang Hongyang's monopolies. See Fa yan 法言 (tr. Nylan), Exemplary Figures: 115 (7.21). 
The Bu Shi narrative ends here, at the point when the agriculturalistentrepreneur has lost his plight to the entrepreneur-official. Sima Qian then sums up: the ancients have shown that during times of peace, agriculture was pursued as a foundation for the state and secondary occupations such as trade were disparaged. In periods of war however (hinting at Han Wudi), "the opposite situation prevailed" (事變多故而亦反是). Sima Qian is sympathetic to Bu Shi's plight and does not rebuke him for failing to understand that Han Wudi's policies needed to be radically reformed. As Hans van Ess notes: "He [Bu Shi] appears like a loyal idealist, but one whose shepherd perspective failed to correctly understand what was really going on in the empire."74 The image of $\mathrm{Bu}$ Shi continues to be used (and abused) to propagate a vision of the model official in contemporary writing. ${ }^{75}$

To illustrate the tension Sima Qian perceives between being a good official on the one hand and having dealings with merchants on the other, we can end with his description of Zhang Tang 張湯, one of the "harsh officials" ( $k u$ li 酷吏). Sima Qian is keen to point out that, while still a petty official, Zhang Tang loved making a profit and hung out with some of Chang'an's wealthiest merchants. Once elevated to high office, Zhang changes his conduct, presumably dissociating himself from his former acquaintances. Zhang then has a deciding hand in issuing laws permitting the confiscation of wealth from property tax evaders, and he goes after big landowners and powerful families. At that point, the balance of moral judgment changes:

74 See van Ess, Politik und Geschichtsschreibung, vol. 2: 577 (Anscheinend ist er ein treuer Idealist, der aber aus seiner Schafzüchterperspektive nicht recht verstand, was im Reiche wirklich vor sich ging). Van Ess concurs that the Bu Shi figure might act as mouthpiece for Sima Qian's own views (p. 582), and argues that Sima Qian's narrative is deliberately created to intimate a spiral of economic decline following Sang Hongyang's monopolies (pp. 584-5).

75 See e.g. Jiang Peng 姜鵬, “Bu Shi: Han chao 'caichan shenbao' di yi ren” 卜式: 汉朝“财 产申报, 第一人 [“Bu Shi: The Han Dynasty's first champion of 'property declaration””]. Renmin luntan 人民论坛 [The People's Discussion Forum] 2 (2013): 78-9; Tang Biaozhong 汤标中, “Fu bu wang guo de shanggu kaimo-Bu Shi” 富不忘国的商贾楷模-卜式 [“A Paragon of the Wealthy Merchant who does not forget his Country: Bu Shi"]. Zhongguo shangren 中国商人 [Chinese Businessmen] 2 (1996): 55; Cui Jianhua 崔建华, “Bu Shi: Han Wudi shidai de daode mofan” 卜式: 汉武帝时代的道德模范 [“Bu Shi: A Virtuous Exemplar from the Time of Han Wudi"]. Wenshi tiandi 文史天地 [Literature and History Omnibus] 1 (2013): 56-9; Li Ran 李然, "Lun Bu Shi yu Han Wudi de jixiang zhengzhi jingqi zhengce” 论卜式与汉武帝的几项政治经济政策 [“On Bu Shi and some of Han Wudi's Government's Economic Policies”]. Qiongzhou daxue xuebao 琼州大学学报 [Journal of Qiongzhou University] 10/6 (2003): 80-2, merely summarizes Ban Gu's narrative and speculates on Bu Shi's potential motives. 
湯之客田甲雖賈人有賢操. 始湯為小吏時與錢通, 及湯為大吏, 甲所以責 晹行義過失, 亦有烈士風.

Among Zhang Tang's friends was a certain Tian Jia who, although a merchant, was a man of worth and upright in conduct. When Zhang Tang was still a petty official, he carried out various money dealings with Tian Jia but once he had become a high minister Tian Jia scolded Zhang Tang about his behaviour and warned him of his faults in the manner of a truly virtuous man. ${ }^{76}$

In a topsy-turvy fashion, the high official's downfall then is partly instigated by evidence extracted from his old merchant friends, who reveal that Zhang, in return for a share in profits, would leak information to them ahead of antimercantile measures issued by Han Wudi so that they could hoard goods and adjust prices. It leads to his death by suicide in 116 вСЕ. When after his death it transpires that Zhang did not leave an estate of the value he was accused of having accumulated as an official, the emperor expresses regret and promotes Zhang's son to a higher post in government. Sima Qian concedes that there is after all some moral currency to be found in a government official.

When Sang Hongyang (d. 8о вСЕ) and his associates introduced the price stabilization, transport measures, and monopolies mentioned in the introduction, they did so against the background of a state that had increasingly lost control over commerce and industry. These were now managed by a group of wealthy negotiators and entrepreneurs who siphoned off revenues. ${ }^{77}$ Sang Hongyang's views on economics survive mostly through the debates between the government party and its critics in Yantie lun. The Debates on Salt and Iron

76 Shiji, 122.3142.

77 Jean Levi inflates the situation slightly in his introduction to the Yantie lun debates: "Sous Han Wudi, tous les fonctionnaires avaient partie liée avec des entrepreneurs et des commerçants et trafiquaient. Une mentalité mercantile et affairiste régnait à tous les échelons de l'administration, infiltrée par les rejetons de ces deux états; elle avait pour finir contaminé la société dans son ensemble. 'Faire du profit' était le maître mot." (Under Han Wudi, all officials were bound up with entrepreneurs and merchants and were trafficking (goods). A mercantile and wheeler-dealer mentality took hold of all levels of the administration that was infiltrated by offspring of these two groups. They had in the end contaminated society altogether: "making profit" was the key slogan). Cf. Levi, La Dispute, intro: 26 . 
purports to be an account of court debates held in 81 BCE (under Emperor Zhaodi) but it is not a direct record of them. Compiled at least three decades later, the text more likely reflects views held during the early years of Yuandi 元帝 (48-33 BCE).$^{78}$ It is difficult however to historicize its rhetoric accurately. The text offers a reflection on the economic policies of Han Wudi but, more importantly, it engages with what must have been perceived as the broader fundamentals of the political economy during the middle and latter part of Western Han.

A great deal of the debate in the Yantie lun starts from the assumption that farming and commerce are mutually opposing forces. Yet it is noteworthy that, in their arguments for a return to the agricultural state, Sang Hongyang's detractors-the so-called Literati or Classical Scholars (wenxue 文學) and Worthies (xianliang 賢良)—focus on elements that have little or nothing to do with economics; rather, they describe the human psychology desired of malleable subjects. This transpires in the critics' opening statement when they point out that government monopolies have caused people to vie for profit:

是以百姓就本者寡, 趨末者眾。夫文繁則質衰，末盛則質虧。末修則
民淫，本修則民㷫。民㷫則財用足，民侈則饑寒生。原罷鹽、鐵、酒
榷、均輸, 所以進本退末, 廣利農業, 便也。

Therefore, those among the common people who take up the fundamental pursuits of life are few while those who rush to the non-essential are manifold. Now, when artificiality flourishes, basic substance declines. When the branches thrive, the basic substance will wane. When the branches are cultivated, the people will overindulge; when the roots are cultivated, people will be reserved [que 㷫]. When people are reserved, there are sufficient resources. When people are extravagant, cold and hunger will follow. We wish that the salt, iron, and alcohol monopolies and the "equal supply" system be abolished. This is how basic pursuits

78 For a summary of the main themes of the debate, see Michael Loewe, Crisis and Conflict in Han China, 104 BC to AD 9 (London: George Allen \& Unwin, 1974): chapter 3. Loewe dates it ca. $44 \mathrm{BCE}$, and argues that it was written to lend weight to those arguing for the abolition of the government monopolies at the time, possibly citing Gong Yu's arguments. See Loewe, Dong Zhongshu: 25, 16o, n. 176; Loewe, "Han Yuandi, reigned 48 to 33 BCE, and His Advisors." Early China 35-36 (2012-13): 364, 387-9o. In what follows I present the arguments mostly as a debate between two parties. Anatoly Polnarov has teased out different strategies, nuances and disagreements among the block that makes up the government's critics (the Worthies and Literati) but these do not seem to affect the general perception among them of agriculture as the primary occupation. See "Looking beyond the Dichotomies: Hidden Diversity of Voices in the Yantielun." T'oung Pao 104 (2018): 465-95. 
may be encouraged and people be deterred from entering the branch occupations, and agriculture may be extended to the widest possible benefit. It is the appropriate thing to do. ${ }^{79}$

The term que 㷫 (MC khaewk) connotes an attitude that is reserved, shy, guileless, naïve, transparent and ingenuous, in other words, an unquestioning mind. This notion that the farmer's mind embraces simplicity — captured by terms such as zhi 質 and ben 本—is emphasized throughout the arguments of the so-called reformists: lead the people with virtue, control their desires with ritual precepts (yi liyifang minyu 以禮義防民欲), and the grain economy will suffice to ensure social stability. Remaining true to the authenticity of the self-sufficient agrarian state in antiquity forges good citizenship. The rhetoric here is reminiscent of Dong Zhongshu's suggestion above that the farming mind delights in following superiors. So, the professions are associated with behaviours that are either deemed beneficial or detrimental to the state. The emphasis is on those who reap the grain rather than the grain itself. Merchants and craftsmen should merely be ancillary to agriculturalists, and the market should only facilitate the circulation of tools and products in the service of the basic occupation of farming. ${ }^{80}$ Unlike the purity of intent and focus that comes with farming, the merchant's psychology is one that premeditates $(y u$ 豫) and swindles ( $z h a$ 詐), while artisans cheat (wei 偽) and provoke dispute ( $m a$ 駡). Only land redistribution according to the well-field model and a reasonable land tax in the form of a tithe would restore the primary profession and the values it embodies. ${ }^{81} \mathrm{~A}$ docile mind and all-consuming dedication to one singular task also implies that the peasant does not, or should not, harbour a desire to step beyond his fields. The ancients, the argument goes, stuck to their profession: officials did not farm and farmers did not fish, the simple and the clever were able to work alongside each other without undermining each other (yu zhi tong gong bu xiang qing ye 愚智同功不相傾也). ${ }^{82}$ In other words, farmers are productive since their labour occupies their entire time and leaves no space to entertain a life other than one of passive receptiveness. Bearing hardship therefore is an admirable part of the human condition and the critics even argue that there is virtue in poverty, as many exemplars from the past have demonstrated. ${ }^{83}$ Tamara Chin, who has analysed Yantie lun from

79 Yantie lun jiaozhu, 1.1 ("Ben yi").

80 Yantie lun jiaozhu, 1.3 ("Ben yi"), 12.162 ("You bian").

81 Yantie lun jiaozhu, 2.28-2.29 ("Li geng"), 15.191 ("Wei tong”).

82 Yantie lun jiaozhu, $4 \cdot 56$ ("Cuo bi").

83 Yantie lun jiaozhu, 16.209 ("Di guang"); 17.221 ("Pin fu”). On poverty as a relative concept or sign of dignity in pre-imperial texts, see Antje Richter, "Die Wahrnehmung von Armut 
a literary perspective as an oppositional model to the Guanzi's "Qing zhong" 輕重 ("Light and Heavy") chapters, concludes that the root (ben) metaphor for the government's critics "is not so much a metonym for agriculture ... as an ethical truism: 'agriculture-is-the-fundamental-human-value'. ${ }^{84}$

By contrast, the government party surrounding Sang Hongyang takes merchants and the other professions as a positive force. Their argument is that agriculture (i.e. a nonmarket world) does not suffice to maintain either the household economy or the demands on the state's treasury. The sages multitasked, Shun 舜 was a potter, Yi Yin 伊尹 a cook. ${ }^{85}$ Therefore, the branch occupations are an indispensable outlet for the produce and wealth generated by the root profession. Agrarian commerce (nong shang jiaoyi 農商交易) embodies that necessity. Wealth is not simply generated on fields and mulberry plantations, but through budgeting and accounting. ${ }^{86}$ Thus the professions are interdependent, and unlike the ideal of agrarian self-sufficiency, diagnosing the interchange between demand and supply and remedying this by circulating goods and produce should be the core task of the state. Craftsmen are there to supply farmers with tools, and sub-standard implements result in bad harvests. 87

Like their opponents, the government party in the debate also divides the population into those who are clever ( $z h i$ 智) and those who are ignorant or stupid ( $y u$ 愚), and they identify the former as people able to mobilize labour

im Alten China." In China und die Wahrnehmung der Welt, ed. Antje Richter and Helmolt Vittinghoff (Wiesbaden: Harrassowitz Verlag, 2007): 1-20 (esp. p.13ff.).

84 Chin, Savage Exchange: 53. Chin shows how the personified dialogues in the Guanzi's "Qing zhong" chapters offer a quantitative and market-oriented model of economics (including monetary theory) that departs from the ethical treatment of economics that predominates Warring States "Masters" texts and is carried on, in varying degrees, by the figures and personae discussed in this paper (although to a lesser degree by Sima Qian and Sang Hongyang). Chin unfolds how the rhetoric and language in these Guanzi chapters offer a counterpoint to traditional classicist views of economics. See Chin, Savage Exchange: 31-68. Since the Yantie lun debates cover a wide range of topics beyond economics and the Guanzi's "Qing zhong" chapters are (even more) difficult to tie to historical personalities or events, I do not discuss them further here but refer the reader to Chin's excellent study. For a discussion of "root" versus "branch" occupations in the earlier (preHan) layers of the Guanzi see Sterckx, "Ideologies of the Peasant and Merchant": 235-40.

85 Yantie lun jiaozhu, 2.28 ("Li geng"). Narratives surrounding Yi Yin are discussed at length in Roel Sterckx, Food, Sacrifice and Sagehood in Early China (New York: Cambridge University Press, 2011): 65-76.

86 Yantie lun jiaozhu, 3.43 ("Tong you"); 14.178 ("Qing zhong”). Tamara Chin (Savage Mind, chapter 1) sees this contrast between arithmetic versus moral reasoning as a main distinguishing element in the economic thought of the period.

87 Yantie lun jiaozhu, 1.3 ("Ben yi"). 
beyond their own and hoard supplies. Agricultural productivity, it is argued, cannot be measured in a vacuum: produce and supplies need to circulate. Human nature's desire to monopolize and hoard wealth and resources is thus best addressed by transferring the power to monopolize exclusively to the state: the ruler accumulates the people's food (and means of remuneration), guards over its consumption, regulates surplus, remedies shortages, and prohibits undue profits and gains. ${ }^{88}$ Ultimately, state monopolies are justified as they ensure that the root profession is strengthened so that stockpiling and accumulating land and wealth (bing jian 并兼) can be stopped..$^{89}$ To safeguard the roots, income generated by the branches needs to be directed to the state. Past models do not serve present circumstances. ${ }^{90}$ And so, morality is embedded within materiality: "the utmost form of filial piety is one that nourishes material countenance" (shang xiao yang se 上孝養色), and no one survives on moral sustenance only. ${ }^{91}$ But, importantly and despite the need for a diversified economy, the ultimate license for enterprise, innovation, or managerial knack must remain entirely with the state:

宇棟之內, 䳡雀不知天地之高; 坎井之蛙, 不知江海之大; 窮夫否 婦, 不知國家之慮; 負荷之商, 不知猗頓之富.

Within the universe, swallows and sparrows know nothing of the distance between Heaven and Earth; "frogs in a well" know nothing of the vastness of rivers and seas; poverty-stricken bumpkins and their stupid wives know nothing about the considerations of statecraft. Peddlers shouldering their packs on their backs know nothing of the wealth of Yi Dun. ${ }^{92}$

88 Yantie lun jiaozhu, 4.56 ("Cuo bi”).

89 Yantie lun jiaozhu, 6.78 ("Fu gu"). The term bingjian occurs in Warring States texts (such as the Shangjun shu and Zhuangzi) with a primary meaning of annexing or incorporating another state and appropriating its resources. In Han texts it continues to connote the amassing of (landed and other types of) wealth. See e.g. Guanzijiaozhu 管子校注 (edited by Li Xiangfeng 黎翔鳳; Beijing: Zhonghua Shuju, 2004): 22.1433 (“Qing zhong, jia”). By implication, it refers to gaining economic advantage by engaging in multiple professions.

$90 \quad$ Yantie lun jiaozhu, 10.130 ("Ci fu").

91 Yantie lun jiaozhu, 25·309-10 ("Xiao yang").

92 Yantie lun jiaozhu, 6.79 ("Fu gu"). For a similar idea see Yantie lun jiaozhu, 16.209 ("Di guang"). "Frogs in a well" alludes to a well-known story in the "Qiu shui” 秋水 (“Autumn Waters") chapter of the Zhuangzi. Yi Dun is a Chunqiu figure from the state of Lu often quoted as paragon of wealth. He is alleged to have made his fortune by herding cattle and sheep and producing sea salt. See Shiji, 129.3259; Hanshu, 91.3685; Shuijing zhu jiaoshi 水經注校釋, ed. Chen Qiaoyi 陳橋驛 (Hangzhou: Hangzhou Daxue Chubanshe, 1999): 6.109. 
What unites both parties in the Yantie lun debates is a firm belief that the state ultimately is the best arbiter of both human and material resources. Sang Hongyang's view of the past is one of a society where the basic and peripheral professions each play their role and complement each other. Unlike Dong Zhongshu, Chao Cuo, or the Worthies and Literati in Yantie lun who turned to the past for an idealised model of the agrarian community, Sang invokes the past for an idealized model of the market. Sang's market functions as both the spatial and temporary catalyst for the circulation of goods: it is a space where the professions and their goods temporarily meet before they each disperse again according to their own laws. This emphasis on the movement or circulation of goods-also illustrated with a medical analogy likening the flow of goods to the circulating of blood and $q i$ through the vessels ${ }^{93}$-allows him to identify accountancy ("method and calculation") and distance to the market as a key measure for the generation of wealth:

故物豐者民衍, 宅近市者家富。富在術數, 不在勞身; 利在勢居, 不在 力耕也。

Where goods abound, people multiply; when one's residence is near a market, a household will get rich. Getting rich depends on "methods" and "statistical calculation", not on hard manual labour; profits depend on one's circumstance of residence, not on strenuous farming. ${ }^{94}$

Since the state is to control the flow of goods, Sang Hongyang's relaxed stance on commerce and crafts in the end boils down to an argument about the reach of the state. As Donald Wagner comments, the government "sees society as a coherent unit, united by trade, whose functions can be optimized by appropriate interventions from the state." 95

To sum up, the Yantie lun parties offer two distinct views of economic endeavour: a model that emphasizes the circulation of people, versus one that stresses autarky and residency tied to the land; a model that favours flexible and porous borders geared towards attracting foreign goods, versus one that sees trade as a mechanism through which wealth seeps out to the periphery. One view advocates multi-tasking, the other insists on the strict separation of

93 Yantie lun jiaozhu, 14.180 ("Qing zhong”).

94 Yantie lun jiaozhu, 3.41 ("Tong you").

95 Donald Wagner, The State and the Iron Industry in Han China (Copenhagen: Nordic Institute of Asian Studies, 2001): 29. 
the professions. One model acknowledges that a modicum of material wealth beyond subsistence level is desirable; the other advocates basic survival and the avoidance of any type of excess beyond basic sustenance. One model sees the use of "accountancy" (calculation) as a positive element in economic management whereas the other proposes a more autarkic management of resources. One view supports and condones humans' instinctive desire for material possessions while the other presents poverty as a moral stance. Yet, amid these diverging views, both parties agree on one central tenet: the need for the state to control the flow of both people and goods.

As we have seen, the pro-agriculturalist rhetoric prevalent under Wendi and Jingdi became more qualified or, one might argue, even dissipated briefly as Han Wudi's reign went on. By Yuandi's (49-33 BCE) time however the battle of ideas swung again in the direction of those who pleaded in an unqualified manner in favour of farming and the need for thrift. Most poignant in his description of the fate of farming folk anno $44 \mathrm{BCE}$, was grand secretary Gong Yu 貢禹 $(124-44$ BCE):

商賈求利, 東西南北各用智巧, 好衣美食, 歲有十二之利, 而不出租 稅。農夫父子暴露中野, 不避寒暑, 捽中杷土, 手足胼胝, 已奉穀租, 又出稁稅, 鄉部私求, 不可勝供. 故民棄本逐末, 耕者不能半。貧民雖 賜之田，猶賤賣以賈， 窮則起為盜賊。何者？末利深而惑於錢也.

Traders and small-scale merchants all seek profit. East, west, south and north, everywhere they apply their wisdom and craftiness and are able to dress with fine clothing and enjoy good food. Each year the merchant makes a profit of twenty percent [on his capital] and yet he pays no tax. In the case of the farmer, father and son are exposed in the midst of the field, escaping neither heat nor cold. They pull the weeds and harrow the soil so that they suffer from calluses and blisters on both hands and feet. After they have paid a regular tax in kind of grain, and have also paid a hay tax, the private demands solicited by the authorities of the district and the village become too heavy a burden to bear. Therefore, the people give up the fundamental profession and pursue the secondary profession. The farming population is less than half [of the total population]. The poor, though, having been granted land, still sell it cheaply in order to become traders. When their capital is exhausted then they become thieves and 
robbers. Why? It is in the secondary professions that one makes handsome profits and yet it is money that makes one become deluded. ${ }^{96}$

Gong Yu's memorials and his program generally echo the principles of the government's critics in Yantie lun who idealized agriculture and advocated thrift and reduced consumption. ${ }^{97}$ The theme of thrift and frugality in expenditure looms large on his agenda. In advocating the abolition of metal currency in the hope that tax and official stipends in the form of grains and textiles will remedy the draw to commerce, Gong Yu returns to some of the agriculturalist arguments featured by Jia Yi and Chao Cuo. As such he takes a middle ground between the idealized view of a pre-monetary agrarian society and the model of monetized commerce as the engine of the economy. But his proposals to abolish the government's mints and return to payment in kind fell on deaf ears.

\section{Concluding Remarks}

What unites Gong $\mathrm{Yu}$ and the interlocutors in economic debates at the Western Han court discussed above is that they recognize the problem when the agricultural base of society defaults; they also concede that professional specialization and wealth creation through means other than agriculture had increasingly become the norm. Although their proposals and arguments paid rhetorical homage to the pre-imperial past and the agriculturalist language associated with some of its figures and texts, few understood the forces behind the rise of an urban class of new professions. The notion that the ancients, as Xunzi 荀子 once professed, had conceived of labour as neatly assigned to "four professions" was meaningless to them. ${ }^{98}$ And whilst the separation of the

96 Hanshu, 72.3075; Hsu Cho-yun, Han Agriculture: 166-7. See also Hanshu, 24B.1176; Swann, Food and Money: 322 .

97 Gong Yu managed to have the state's iron and salt monopolies suspended, but only until 41 BCE when they were reinstated.

98 The division of labour into four professions, known as the "four people" (si min 四民) is another ideological construct, the historical relevance of which is difficult to test. Based on his tabulation of occurrences in Zhou and Han texts, Derk Bodde once suggested that it was only in the second century вСЕ that the standard sequence of shi, nong, gong and shang (scholars, farmers, artisans, merchants) was firmly established. See Derk Bodde, Chinese Thought, Society and Science (Honolulu: University of Hawai'i Press, 1991): 203$12,369-75$. My view would be that the more rhetorically established or serialized these terms became, the less relevant they were as a reflection of practical reality. Barbieri-Low acknowledges that the law codes do not reflect legal distinctions, but he maintains that 
professions continued to be promoted by some, ${ }^{99}$ in reality this was no more than a faint ideal as later commentators acknowledge. ${ }^{100}$ The agrarian utopia of the well-fields associated with the distant pre-Qin feudal past was as much a fiction as that of the self-sustaining land-owning farmer that emerged from the recent Qin past. Neither offered a model suitable for what had become an increasingly commercialized but, still, predominantly agrarian, economy. Yet equally, as I have argued, few of these Han thinkers conceived of the relative merits of agriculture and commerce on economic grounds.

There was no doubt some truth to the diagnosis that, when too many people engage in commercial activities, there is a shortage of labour on the fields. Yet such explanations proved overly simplistic. Both the early Han emperors' intentions to promote agriculture, and the desired return to the moneyless society as advocated by some after the demise of Han Wudi, were tinged by a language that conceived of the economic as some kind of timeless abstraction. Dividing the world into root and branch occupations or productive farmers versus destructive merchants proved inadequate to explain the complexities of economic life across a vast and highly diverse empire. As a concept it failed to account for a mercantile agrarian economy where farmers were locked into extensive economic networks. The idea that grain only could serve as a medium of value or that farming communities were isolated and self-sufficient units was equally incredible. These black-or-white ideologies often served other aims. For some, as Hsu Cho-yun has noted, it was "a very handy accusation against the relatively prosperous urban professions. It, in fact, remained one of the most common recurring themes in the argument for government promotion of agriculture."101

Neither court advisors who were prospecting future policy, nor indeed historians reporting on their recommendations, were able to escape the inevitable task of having to phrase their proposals in view of a real or virtual economic past. Han arguments regarding wealth creation were pegged onto a narrative of decline: how had contemporary imbalances been allowed to come about?

si min rhetoric still made "these groups realize some level of class consciousness". See Barbieri-Low, Artisans in Early Imperial China: 37.

99 See, e.g., Huainanzi honglie jijie 淮南子鴻烈集解 [Collected Explanations of the Grand Achievements of The Master Huainan], ed. Liu Wendian 劉文典 (Taipei: Wenshizhe Chubanshe, 1992): 11.368 ("Qi su"), for another passage describing the physical and geographical separation of the professions as a sign of the perfectly ordered society. See also Huainanzi, 9.281 ("Zhu shu").

100 For criticism of the economic rationale for separating the professions see e.g. Hou Hanshu, 39.1305; or comments by Jiang Tong 江統 (d. 310 CE) in Jinshu 晉書 [Book of Jin], compiled by Fang Xuanling 方玄齡 et al. (Beijing: Zhonghua Shuju, 1974), 56.1537.

101 Hsu Cho-yun, Han Agriculture: 25. 
Opinions differed as to when an erstwhile harmonious society precipitated into social and economic regression, but most strategies for wealth creation and the containment of poverty were presented to the court as restorative projects rather than as strategies for innovation. Economic progress was mostly defined as a process that would bring society back to a point of equilibrium and political control, as it had possibly existed in a more immediate or distant past. To no great surprise, discussions on the economic management of the state were routinely channelled through actors and voices set in the pre-Han past. ${ }^{102}$ In court rhetoric, new ideas about wealth creation could only be formulated in the voice of the ancients, albeit that the points of reference to the past varied significantly.

The fact that, to many in Western Han, wealth creation through commerce and the discourse on the merchant's psychology and behaviour were clad in a veneer of disapproval and negativity should not come as a surprise. Anti-mercantile rhetoric is rarely exclusively based on economic arguments but is inspired by a host of other elements. Such too was the case in the Greco-Roman world, as Neville Morley points out: "The disparaging attitude of many ancient sources towards trade and traders, frequently blamed for the limited economic development of antiquity, is often a strategy of self-positioning in relation to a set of ideals and values - whether that of the true aristocrat, the good citizen, the traditionally minded Roman or the faithful Christian."103 In Han China, as in Rome, disdain for trade went hand in hand with the overidealization of agriculture. ${ }^{104}$ In court rhetoric, political expedience dictated that agriculturalist language could not to be dismissed since it perpetuated, like a genetic imprint from a utopian past, a view of human psychology that served and suited those wielding power over a centralized empire: a registered population of hardworking, uneducated and unquestioning subjects dedicated to communal labour. There were no taboos on wealth creation as such, only

102 The best example of this are exchanges between Duke Huan 桓公 of Qi (685-643 BCE) and Guan Zhong 管仲 in the economic chapters of the Guanzi, which nearly all date to Western Han. Another example is Sang Hongyang's party who explicitly identify Guan Zhong's economic policies as the inspiration for the iron and salt monopolies and a twopronged approach giving weight to both agriculture and trade. See Yantie lun jiaozhu, 14.178 ("Qing zhong"). Yantie lun jiaozhu, 1.3 ("Ben yi") quotes a passage absent from the transmitted Guanzi to make the point that artisans and merchants are indispensable to transform natural resources into goods and trade them.

103 Neville Morley, Trade in Classical Antiquity (Cambridge: Cambridge University Press, 2007): 14 .

104 Roman agricultural writers appear very generous with information on how to run their estates and achieve maximum profits but, as Morley notes, "they are remarkably coy about the subject of actually marketing their goods". See Morley, Trade in Classical Antiquity: 83 . 
on the maintenance of power and control over those segments in society that proved enterprising. The merchant was blacklisted not for his knack at generating profit but for his propensity to generate wealth beyond the reach of the centre. Perhaps, for the first time in Chinese history, a realization grew during Western Han that, for commerce or an economy at large to be really successful, it requires the energy and a modicum of courage to contest authority and pursue a course to wealth other than what court ideologues had officially sanctioned.

\section{Acknowledgments}

I would like to thank the three anonymous reviewers for their generous comments, suggestions and corrections. I am also grateful to Michael Loewe, Christian Schwermann, Elisa Sabattini, Yang Fu and Hajni Elias for combing through an earlier version of this paper.

\section{Bibliography}

\section{Primary Sources}

Bohutong shu zheng 白虎通疏證 [The Comprehensive Discussions in the White Tiger Hall with commentaries]. Compiled by Ban Gu et al., annotated by Wu Zeyu 吳則虞. Beijing: Zhonghua Shuju, 1994.

Fa yan 法言 [Exemplary Figures]. By Yang Xiong 揚雄 (53 BCE-118 CE); tr. Michael Nylan, Exemplary Figures. Seattle and London: University of Washington Press, 2013. Guanzijiaozhu 管子校注 [The Master Guan with Collated Commentaries]. Edited by Li Xiangfeng 黎翔鳳. Beijing: Zhonghua Shuju, 2004.

Han shi waizhuan jishi 韓詩外傳集釋 [Collected Explanatory Commentaries on Han

Ying's Illustrations of the Didactic Application of the Book of Songs]. By Han Ying 韓嬰 (fl. ca.150 BCE), ed. Xu Weiyu 許維頟. Beijing: Zhonghua Shuju, 1980.

Hanshu 漢書 [Book of Han]. Compiled by Ban Gu 班固 (32-92 CE). Beijing: Zhonghua Shuju, 1962.

Hou Hanshu 後漢書 [Book of Later Han]. Compiled by Fan Ye 范瞱 (398-445 CE) et al. Beijing: Zhonghua Shuju, 1965.

Huainanzi honglie jijie 淮南子鴻烈集解 [Collected Explanations of the Grand Achievements of The Master Huainan], ed. Liu Wendian 劉文典. Taipei: Wenshizhe Chubanshe, 1992.

Jinshu 晉書 [Book of Jin]. Compiled by Fang Xuanling 方玄齡 (578-648 CE) et al.

Beijing: Zhonghua Shuju, 1974. 
Lijizhushu 禮記注疏 [The Record of Rites with commentaries and subcommentaries], annotated by Kong Yingda 孔穎達 (574-648 CE). In Shisanjing zhushu 十三經注疏, collated by Ruan Yuan 阮元 (1764-1849); rpt. Taizhong: Landeng, n.d., vol. 5 .

Maoshi zhengyi 毛詩正義 [The Correct Meanings of the Mao Edition of The Odes], Shisanjing zhushu edition, vol. 2.

Ri zhi lu 日知錄 [Record of Daily Knowledge, 1695]. By Gu Yanwu 顧炎武 (1613-1682).

See Ian Johnston tr., Record of Daily Knowledge and Collected Poems and Essays: Selections. New York: Columbia University Press, 2017.

Sanguo zhi 三國志 [Records of the Three Kingdoms]. Compiled by Chen Shou 陳壽 (233-297 CE). Beijing: Zhonghua Shuju, 1959.

Shangshu zhengyi 尚書正義 [The Correct Meanings of the Book of Documents]. Annotated by Kong Yingda 孔穎達 et al. Shisanjing zhushu edition, vol. 1.

Shiji 史記 [Records of the Grand Historian]. By Sima Qian 司馬遷 (ca. 145-ca. 87 BCE). Beijing: Zhonghua Shuju, 1959.

Shuijing zhu jiaoshi 水經注校釋 [Collated Explanatory Commentaries to the Water Classic Commentary]. Edited by Chen Qiaoyi 陳橋驛. Hangzhou: Hangzhou Daxue Chubanshe, 1999.

Xinshu jiaozhu 新書校注 [Annotated commentary to New Writings], ed. Yan Zhenyi 閻振益 and Zhong Xia 鍾夏. Beijing: Zhonghua Shuju, 2000.

Yantie lun jiaozhu 鹽鐵論校注 [The Debates on Salt and Iron with annotations and commentary]. Compiled by Huan Kuan 桓寬 (1st century BCE), annotated by Wang Liqi 王利器. Beijing: Zhonghua Shuju, 1996.

Zhangjiashan Han mu zhujian [ershiqi hao mu] 張家山漢墓竹簡 [二十七號墓] [Bamboo Manuscripts from Han Tomb no. 27 at Zhangjiashan], ed. Zhangjiashan ershiqi hao Han mu zhujian zhengli xiaozu, Beijing: Wenwu Chubanshe, 2006.

\section{Secondary Sources}

Barbieri-Low, Anthony. 2007. Artisans in Early Imperial China. Seattle \& London: University of Washington Press.

Bielenstein, Hans. 1980. The Bureaucracy of Han Times. Cambridge: Cambridge University Press.

Bodde, Derk. 1975. Festivals in Classical China: New Year and other annual observances during the Han dynasty, 206 B.C.-A.D. 220. Princeton: Princeton University Press.

Bodde, Derk. 1991. Chinese Thought, Society and Science. Honolulu: University of Hawai'i Press.

Chen Ying 陈英. 2010. Handai pin fu chaju yu zhengfu kongzhi yanjiu 汉代贫富差距 与政府控制研究 [A Study of Wealth Disparity and Government Control during the Han Dynasty]. Beijing: Zhongguo Shehui Kexue Chubanshe.

Chin, Tamara T. 2014. Savage Exchange. Han Imperialism, Chinese Literary Style, and the Economic Imagination. Cambridge, MA: Harvard University Press. 
Ch'ü T'ung-tsu 睢同祖. 1972. Han Social Structure. Seattle and London: University of Washington Press.

Cui Jianhua 崔建华. 2013. Bu Shi: Han Wudi shidai de daode mofan 卜式:汉武帝时 代的道德模范 [Bu Shi: A Virtuous Exemplar from the Time of Han Wudi]. Wenshi tiandi 文史天地 1: 56-9.

Di Cosmo, Nicola. 2002. Ancient China and its Enemies. The Rise of Nomadic Power in East Asian History. Cambridge: Cambridge University Press.

Ding Bangyou 丁邦友. 2009. Handai wu jiaxin tan 汉代物价新探 [A New Discussion of Commodity Prices during the Han]. Beijing: Zhongguo Shehui Kexue Chubanshe.

Ding Bangyou and Wei Xiaoming 魏晓明. 2016. Qin Han wu jia shiliao huishi 秦汉 物价史料汇释 [Explanatory Collection of Historical Materials on Qin and Han Commodity Prices]. Beijing: Zhongguo Shehui Kexueyuan Chubanshe.

Gao Weigang 高维刚. 2008. Qin Han shichang yanjiu 秦汉市场研究 [A Study of Markets during Qin and Han]. Chengdu: Sichuan Daxue Chubanshe.

Graham, Angus. 1979. The Nung-chia 'School of Tillers' and the Origins of Peasant Utopianism in China. Bulletin of the School of Oriental and African Studies 42/1: 66-10o.

Graziani, Romain. 2019. What's in a Slogan. The Political Rationale behind 'Enrich the State, Strengthen the Army' (富國強兵) and its economic quandary. In Keywords in Chinese Culture, ed. Li Wai-yee and Yuri Pines. Hong Kong: The Chinese University Press: $123-68$.

Gu Jiguang 谷䨖光. 1944. "Zhanguo Qin Han zhong nong yi shang zhi lilun yu shiji” 戰國秦漢重農抑商之理論與實際 [“The Theory and Practice of Promoting Agriculture and Suppressing Trade during the Warring States, Qin and Han periods"], Zhongguo shehui jingji shi jikan 中國社會經濟史集刊 [Collected Papers in Chinese Socio-Economic History] 7: 1-22.

Han Fuzhi 韓復智. 1969. Liang Han de jingji sixiang 兩漢的經濟思想 [Economic Thought during the Former and Later Han]. Taipei: Taiwan Shangwu Yinshuguan.

Hsu Cho-yun 許倬雲. 1980. Han Agriculture. The Formation of Early Chinese Agrarian Economy (206 B.C. - A.D. 220). Seattle and London: University of Washington Press. $\mathrm{Hu}$ Jichuang 胡寄窗. 1981. Zhongguo jingji sixiang shi jianbian 中国经济思想史简 编 [A Concise History of Economic Thought in China]. Beijing: Zhongguo Shehui Kexue Chubanshe.

Hui Fuping 惠富平. 200o. Shijiyu Zhongguonongye 史记与中国农业 [The Historical Records and Chinese Agriculture]. Xian: Shaanxi Renmin Chubanshe.

Jiang Peng 姜鵬. 2013. Bu Shi: Han chao ‘caichan shenbao' di yi ren 卜式: 汉朝“财产 申报第一人 [Bu Shi: The Han Dynasty's first champion of 'property declaration']. Renmin luntan 人民论坛 2: 78-9.

Karl, Rebecca E. 2017. The Magic of Concepts. History and the Economic in Twentieth-Century China. Durham, NC: Duke University Press. 
Leung, Vincent S. 2019. The Politics of the Past in Early China. Cambridge: Cambridge University Press.

Levi, Jean. 2010. Dispute sur le sel et le fer. Paris: Les Belles Lettres.

Lewis, Mark Edward. 2007. The Early Chinese Empires. Qin and Han. Cambridge, MA: The Bellknapp Press of Harvard University Press.

L'Haridon, Béatrice. 2015. The Merchants in Shiji: An Interpretation in the Light of Later Debates. In Views from Within, Views from Beyond: Approaches to the Shiji as an early work of historiography, ed. Hans van Ess, Olga Lomová, and Dorothee Schaab-Hanke. Wiesbaden: Harrassowitz Verlag: 171-92.

Li Ran 李然. 2003. Lun Bu Shi yu Han Wudi de jixiang zhengzhi jingqi zhengce 论卜 式与汉武帝的几项政治经济政策 [On Bu Shi and some of Han Wudi's Government's Economic Policies]. Qiongzhou daxue xuebao 琼州大学学报 10/6: 80-2.

Liang Cai 亮蔡. 2014. Witchcraft and the Rise of the Confucian Empire. Albany: State University of New York Press.

Liu Jiapeng 刘甲朋. 2010. Zhongguo gudai liangshi chubei tiaojie zhidu sixiang yanjin 中国古代粮食储备调节制度思想演进 [Evolving Ideologies of the System of Regulation for the Storage of Grain Reserves in Ancient China]. Beijing: Zhongguo Jingji Chubanshe.

Loewe, Michael. 1974. Crisis and Conflict in Han China, 104 BC to AD 9. London: George Allen \& Unwin.

Loewe, Michael. 1985. Attempts at Economic Co-ordination during the Western Han Dynasty. In The Scope of State Power in China, ed. Stuart R. Schram (Hong Kong: Chinese University of Hong Kong Press): 237-66.

Loewe, Michael. 2006. The Government of the Qin and Han Empires. Indianapolis: Hackett.

Loewe, Michael. 2008. The organs of Han imperial government: zhongdu guan, duguan, xianguan, and xiandao guan. Bulletin of the School of Oriental and African Studies 71/3: 509-28.

Loewe, Michael. 2011. Dong Zhongshu, a 'Confucian' Heritage and the Chunqiu fanlu. Leiden: E.J. Brill.

Loewe, Michael. 2012-13. Han Yuandi, reigned 48 to 33 B.C.E., and His Advisors. Early China 35-36: 361-93.

Luo Genze 羅根澤. 1931. Gudai jingjixue zhong zhi ben nong mo shang xue shuo 古代經濟學中之本農末商學説 [The Theory of The Primacy of Agriculture and Subsidiarity of Commerce in the Study of Ancient Economics]. In Guanzi tanyuan 管子探源 [Explorations into the Origins of The Master Guan], ed. Luo Genze 羅根澤 (Shanghai: Zhonghua Shuju), annex 2.

Morley, Neville. 2007. Trade in Classical Antiquity. Cambridge: Cambridge University Press.

Nie Shiqiao 聂石樵. 2010. Sima Qian lungao 司马迁论稿 [Essays on Sima Qian]. Beijing: Zhonghua Shuju. 
Nylan, Michael. 1993. Hsin shu. In Early Chinese Texts. A Bibliographical Guide, ed. Michael Loewe. Berkeley: The Society for the Study of Early China and The Institute of East Asian Studies: 166-8.

Nylan, Michael. 2015. Assets Accumulating: Sima Qian's Perspective on Moneymaking, Virtue, and History. In Views from Within, Views from Beyond: Approaches to the Shiji as an early work of historiography, ed. Hans van Ess, Olga Lomová, and Dorothee Schaab-Hanke. Wiesbaden: Harrassowitz Verlag: 131-70.

Pokora, Timoteus. 1975. Hsin-lun (New Treatises) and Other Writings by Huan T'an (43 $B C 28 A D)$. Ann Arbor: Center for Chinese Studies, University of Michigan.

Polnarov, Anatoly. 2018. Looking beyond the Dichotomies: Hidden Diversity of Voices in the Yantielun. T'oung Pao 104/5-6: 465-95.

Richter, Antje. 2007. Die Wahrnehmung von Armut im Alten China. In China und die Wahrnehmung der Welt, ed. Antje Richter and Helmolt Vittinghoff. Wiesbaden: Harrassowitz Verlag: 1-20.

Rickett, W. Allyn. 1998. Guanzi. Political, Economic, and Philosophical Essays from Early China, vol. 2. Princeton: Princeton University Press.

Sabattini, Elisa Levi. 2019. War economy during the Western Han. In The Political Economy of the Han Dynasty and Its Legacy, ed. Cheng Lin, Terry Peach and Wang Fang. London and New York: Routledge: chapter 7.

Sadao, Nishijima. 1986. The Economic and Social History of Former Han. In the Cambridge History of China. Volume I: The Ch'in and Han Empires, 221 B.C.-A.D. 220, ed. Michael Loewe (Cambridge: Cambridge University Press): 545-648.

Shao Yiping 邵毅平. 2005. Zhongguo wenxue zhong de shangren shijie 中国文学中 的商人世界 [The World of Merchants in Chinese Literature]. Shanghai: Fudan Daxue Chubanshe.

Sou, Daniel Sungbin. 2018. Crossing Borders: Control of Geographical Mobility in Early China. T'oung Pao 3-4: 217-5o.

Sterckx, Roel. 2011. Food, Sacrifice and Sagehood in Early China. New York: Cambridge University Press.

Sterckx, Roel. 2015. Ideologies of the peasant and merchant in Warring States China. In Ideology of Power and Power of Ideology in Early China, ed. Yuri Pines, Paul Rakita Goldin, and Martin Kern. Leiden: Brill: 211-48.

Svarverud, Rune. 1998. Methods of the Way: Early Chinese Ethical Thought. Leiden: E.J. Brill.

Swann, Nancy Lee. 1950. Food and Money in Ancient China. Princeton: Princeton University Press.

Tang Biaozhong 汤标中. 1996. Fu bu wang guo de shanggu kaimo-Bu Shi 富不忘 国的商贾楷模-卜式 [A Paragon of the Wealthy Merchant who does not forget his Country: Bu Shi]. Zhongguo shangren 中国商人 2: 55 .

van Ess, Hans. 2014. Politik und Geschichtsschreibung im alten China. Wiesbaden: Harrassowitz Verlag, 2 vols. 
van Ess, Hans, Olga Lomová, and Dorothee Schaab-Hanke ed. 2015. Views from Within,

Views from Beyond: Approaches to the Shiji as an early work of historiography Wiesbaden: Harrassowitz Verlag.

Wagner, Donald. 2001. The State and the Iron Industry in Han China. Copenhagen: Nordic Institute of Asian Studies.

Wang Yanhui 王彦辉. 2016. Qin Han huji guanliyu fuyi zhidu yanjiu 秦汉户籍管理与 赋役制度研究 [A Study of the Management of Household Registers and the Tax System in Qin and Han]. Beijing: Zhonghua Shuju.

Wu Song 吴松.2000. Zhongguo nong shang guanxi sixiang shigang 中国农商关系思 想史纲 [An Outline of the Relationship between Agriculture and Commerce in the History of Chinese Thought]. Kunming: Yunnan Daxue Chubanshe.

Yang Lien-sheng 楊聯陸. 1957. Economic Justification for Spending一An Uncommon Idea in Traditional China. Harvard Journal of Asiatic Studies 20/1-2: 36-52.

Yu Kunqi 于琨奇. 2012. Zhanguo Qin Han xiao nong jingjiyanjiu 战国秦汉小农经济 研究 [A Study of the Small-Scale Farming Economy during the Warring States, Qin and Han Periods]. Beijing: Shangwu Yinshuguan.

Yü Ying-shih. 1986. Han Foreign Relations. In The Cambridge History of China. Volume I: The Ch'in and Han Empires, 221 B.C-A.D 220, ed. Michael Loewe. Cambridge: Cambridge University Press: 377-462.

Zang Zhifei 臓知非. 2017. Qin Han tudi fuyi zhidu yanjiu 秦汉土地賦役制度研究 [A Study of the Land Tax and Corvée System in Qin and Han]. Beijing: Zhongyang Bianyi Chubanshe.

Zhu Honglin 朱红林. 2003. Zhouli zhong shangye guanli zhidu yanjiu 周礼中商业 管理制度研究 [A Study of the System of Commerce Management in the Rites of Zhou]. Changchun: Jilin Wenshi Chubanshe.

Zhu Jiazhen 朱家禎. (1996) 'Shangshu' ji buci jinwen zhong de jingji sixiang 尚書 及卜辭金文中的經濟思想 [Economic Thought in the Book of Documents, Oracle Bone and Bronze Inscriptions]. In Xian Qin jingji sixiang shi 先秦经济思想史 [A History of Economic Thought in the Pre-Qin Period], ed. Wu Baosan 巫宝三 (Beijing: Zhongguo Shehui Kexue Chubanshe): 6o-79. 